\title{
The Necklace as a Divine Symbol and as a Sign of Dignity in the Old Norse Conception
}

\section{Introduction}

In the last century a wooden sculpture, $42 \mathrm{~cm}$ tall, was found in a small peat-bog at Rude-Eskildstrup in the parish of Munke Bjergby near Sorø in Denmark. (Picture 1) The figure was found standing right up in the peat with its head ca. $30 \mathrm{~cm}$ below the surface. The sculpture represents a sitting man, dressed in a long garment with two crossed bands on its front. His forehead is low, his eyes are tight, his nose is large, and he wears a moustache and a pointed chin-beard. Part of his right arm is missing, while his left arm is undamaged. On his knee he holds an object resembling a bag. Around his neck he wears a robust trisected necklace. ${ }^{1}$ At the bottom the sculpture is finished with a peg, which indicates that it was once attached to a base, which is now missing (Mackeprang 1935: 248-249). It is regarded as an offering and is usually interpreted as depicting a Nordic god or perhaps a priest (Holmqvist 1980: 99-100; Ström 1967: 65).

The wooden sculpture from Rude-Eskildstrup is unique of its kind. But his characteristic trisected necklace is of the same type as three famous golden collars from Västergötland and Öland. The sculpture as well as the golden necklaces belong to the Migration Period, ca. 400-550 A.D. From this period of our prehistory we have the most frequent finds of gold, and very many of the finds from this period are neck-ornaments.

Neck-rings are also frequent in finds from the Early Bronze Age, ca. 1000-550 B.C. Around 1000 years separate these two periods. Far later necklaces are mentioned in the Old Icelandic literature. For instance, the

\footnotetext{
${ }^{1}$ A similar trisected necklace can be seen on a small bronze figure found in a gravemound at Søholt on Lolland. This figure is said to have been placed as a mounting on a wooden stick, with a still preserved ring at its end. A bronze cylinder and a bronze mask were found in the same grave-mound. The symbolism and function of this bronze figure are unknown, but it can help to date the Rude-Eskildstrup sculpture. Both belong to the Germanic Iron Age. See Mackeprang 1935: 245-248.
} 
goddess Freyja was the owner of the Brísingamen necklace, according to Snorri Sturluson in his Edda, written in the $13^{\text {th }}$ century A.D (Snorri Sturluson 1931: 38). He also tells that the god Ódinn was in possession of the ring Draupnir, from which eight new rings fell every ninth night (Snorri Sturluson 1931: 66).

Thus, necklaces appear in three quite distinct eras: the Early Bronze Age, the Migration Period, and the early Middle Ages. Is this interest of our ancestors in neck-ornaments concentrated on these periods, or were they used continuously during this long space of time?

What meaning did the neck-ring have for prehistoric man? The finds indicate that the ring was not only used for decoration, but served other purposes as well. It might have been used as a sign of prestige or it might have had a religious significance.

A necklace and a ring are the attributes of Freyja and Oðinn. Is it possible to find a connection between these divine accessories and the neckornaments which appear so abundantly in the finds from earlier periods? Could such a connection contribute to the understanding of the religion of the Viking Age?

The object of this article is to answer these questions. The starting point is taken in the Migration Period, ca. 500 A.D. and the investigation of neck-rings in southern Scandinavia goes backwards in time through the Roman Iron Age, the Pre-Roman Iron Age, and up to the Early Bronze Age. (See time-sheet.) The necklace as a divine attribute is related to other offerings from these periods. The presence of necklaces in southern Scandinavia is compared to finds of necklaces in Central Europe. Testimonies from classic Greek and Roman authors concerning the use of neck-rings among Germanic and Celtic people add to the picture. Finally the finds of neckornaments during the Vendel and Viking Age are investigated as well as the necklace as a theme in Old Icelandic literature.

\section{Necklaces from the Migration Period (400-550 A.D.)}

\section{The golden necklaces from Västergötland and Öland, Sweden}

As I have mentioned, the neck-ring carried by the sculpture from RudeEskildstrup is of the same type as the famous golden necklaces from Västergötland and Öland. They consist of a number of tubes, three, five and seven, bent as rings and placed beside each other. The gold collars are divided in two halves connected by a hinge, by means of which they can be opened. Their diameter is largest at the opening, to be placed on the chest 


\section{Time sheet}

Sweden and Denmark

\begin{tabular}{|c|}
\hline $\begin{array}{l}\text { Early Middle Ages } \\
1050-\end{array}$ \\
\hline $\begin{array}{l}\text { Viking Age } \\
800-1050\end{array}$ \\
\hline $\begin{array}{l}\text { Vendel Age = } \\
\text { Late Germanic Iron Age } \\
550-800\end{array}$ \\
\hline $\begin{array}{l}\text { Migration Period = } \\
\text { Early Germanic Iron Age } \\
400-550\end{array}$ \\
\hline $\begin{array}{l}\text { Roman Iron Age } \\
0-400\end{array}$ \\
\hline $\begin{array}{l}\text { Pre-Roman Iron Age = } \\
\text { Celtic Iron Age } \\
500 \text { B.C. }-0\end{array}$ \\
\hline $\begin{array}{l}\text { Late Bronze Age } \\
\text { 1000-500 B.C. }\end{array}$ \\
\hline
\end{tabular}

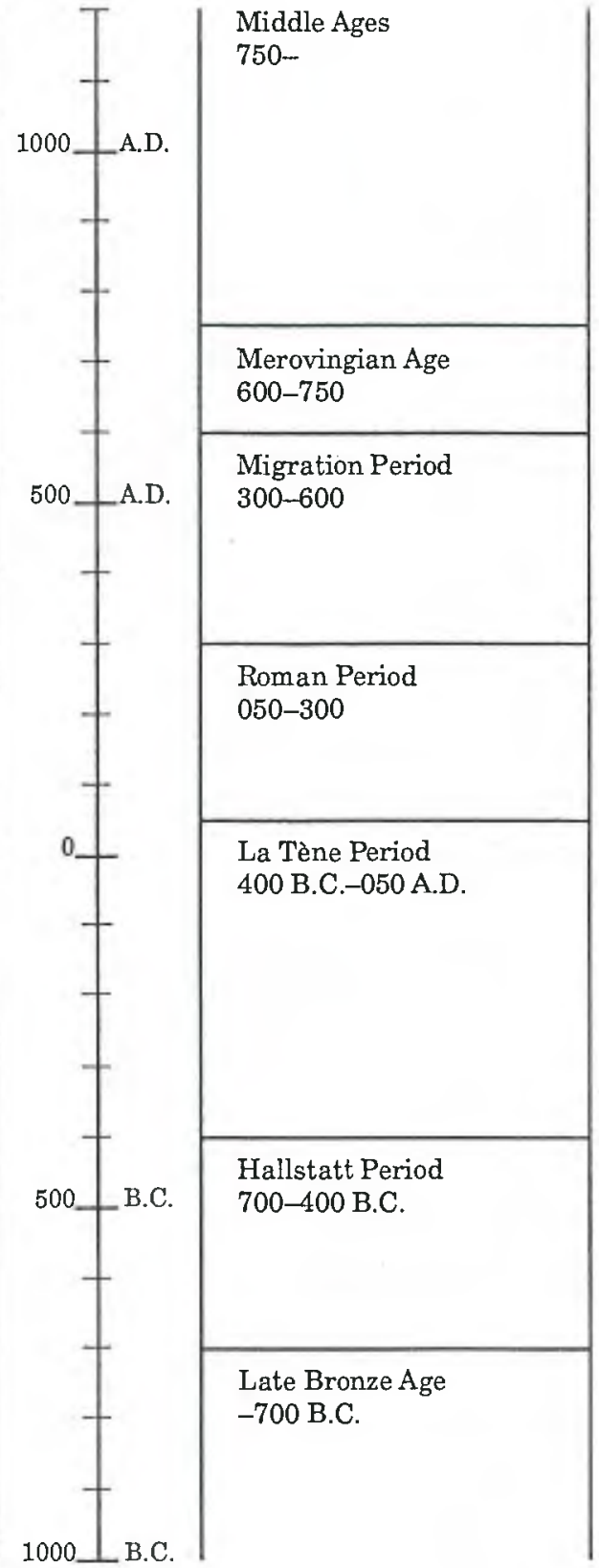

\section{Central Europe}

\section{Middle Ages}

Merovingian Age

Migration Period

$00-600$

Roman Period

050-300

La Tène Period

400 B.C. -050 A.D.

Hallstatt Period $700-400$ B.C

Late Bronze Age

-700 B.C 
of the wearer, and smallest at the hinge, to be placed on the nape of the neck. The tubes are decorated with a number of larger and smaller bulges. Between the tubes small golden plates with engraved pictures, representing animals, human beings, and geometric figures, have been fixed. ${ }^{2}$

The design of the collars as well as the technical details, such as the hinge, connect them to South-East Europe. Holmqvist, who has made a thorough study of the necklaces, finds their closest counterpart in a cloissonné decorated golden necklace from Petroassa in present Romania (Holmqvist 1980: 21).

Two men found the first golden necklace in 1827 at the foot of a steep hill at Ålleberg in Västergötland, while looking for stones suitable for use in baking ovens. The necklace from Alleberg is damaged and might have been divided into pieces when discovered. It is composed of three tubes, decorated with exquisite filigree-work and a dense granulation. Its maximum diameter is $19.5 \mathrm{~cm}$ and its smallest $17 \mathrm{~cm}$. It weighs $620 \mathrm{gr}$.

A second gold collar was found as soon as in 1860 at Färjestaden on Öland. It consists of five tubes with a total weight of 707 gr. Its maximum diameter is $22.6 \mathrm{~cm}$ and its smallest $18 \mathrm{~cm}$. The goldsmith's work is perfect.

Four years later the crofter Johannes Andersson found a still larger golden necklace in a mound of stones at Möne in Västergötland. (Picture 2) The mound is only $25 \mathrm{~km}$ from the site where the gold collar from Alleberg had been found. It consists of seven tubes with a total weight of as much as $820 \mathrm{gr}$. Its maximum diameter is $21 \mathrm{~cm}$ and its smallest $15.5 \mathrm{~cm} .^{3}$

Holmqvist considers the gold collars to be of Nordic origin and created by three different masters, and he dates them to the sixth century A.D. (Holmqvist 1980: 27-29, 84). Thereby he refers to the understanding of Oscar Montelius, who also regards them as local products, but created during the fifth century A.D. (Montelius 1912: 11-12). Holmqvist suggests that the magnificent collars might have been part of the king's/priest's equipment (Holmqvist 1980: 99).

These necklaces are all stray finds from the $19^{\text {th }}$ century. As the detailed circumstances around the discoveries are not known, they cannot contribute to the understanding of their original use.

\footnotetext{
${ }^{2}$ Holmqvist 1980 and Lamm 1991 both give accurate descriptions of the appearance and construction of the necklaces. Lamm 1991 tries to construct a system by means of which one can orient oneself among the motives.

${ }^{3}$ Concerning the history of the finds see Holmqvist 1980: 10-11.
} 


\section{Köinge, Halland, Sweden}

The collars from Öland and Västergötland are not the only ones of their kind. At Köinge in Halland fragments have been found of a still larger necklace of the same type. These fragments indicate that its diameter was ca. $30 \mathrm{~cm}$. According to Holmqvist it is unlikely to have been used by a human being, because of its size. He is more inclined to think that it was created for a god, like the collars from Västergötland and Öland (Holmqvist 1980: 17). ${ }^{4}$

\section{Hannenov, Falster, Denmark}

The Swedish rings have counterparts on Danish territory. In 1937 a farmer, ploughing a field at Hannenov on the island of Falster, found a thick golden ring with alternating large and small bulges. (Picture 3 ) The ring has a diameter of $24-25 \mathrm{~cm}$ and weighs $526.3 \mathrm{gr}$. Its gold content is $84 \%$. It is abundantly ornamented with filigree-work and decorated with animal figures. Like its Swedish counterparts it is considered to be a local product. The style of the animal figures, which is interesting from a historical point of view, indicates, according to Brøndsted, that the ring was created during the first half of the fifth century A.D. Munksgaard, however, dates it prior to ca. 500 A.D. The meadow where the Falster collar was found was a bog in prehistoric times, and the neck-ring was probably deposited there as an offering. ${ }^{5}$

\section{Hjallelse, Fyn, Denmark}

In all essentials, the Hannenov ring resembles another necklace from Hjallelse, situated south of Odense on the island of Fyn, which was found the year before, in 1936. (Picture 4) The ring from Hjallelse was also found during ploughing and was damaged by the plough. It is made of one big tube, equipped with bulges of different thickness. It is decorated with stars and suns, triangles and pairs of curves. The hinge and the end of the tube are missing, although the ring was probably complete when found. Its inner diameter is $36-37 \mathrm{~cm}$ and its weight 459 gr. Its gold content is $90 \%$.

\footnotetext{
${ }^{4}$ Montelius, in his day, however, argued that the size of the ring should indicate its use as a belt and not as a collar. See Montelius 1912: 12-13.

${ }^{5}$ For investigations of the Hannenov ring see Brøndsted 1938 and Munksgaard 1952. Even Holmqvist 1980 has a discussion of the Danish rings in relation to the Swedish necklaces.
} 
Brøndsted and Munksgaard both date the necklace from Hjallelse back to the beginning of the Germanic Iron Age. ${ }^{6}$

\section{Other neck-rings from 400-550 A.D.}

In addition to the neck-rings discussed above, some 50 large rings, mainly from Denmark and Sweden, but also from southern Norway and northern Germany, have been dated to the same period, 400-550 A.D. Among these, two types can be discerned. One type is made of a single golden bar, thinner at the back and thicker at the front, where the two thick ends are crossed over each other to some length. This kind of ring, which cannot be opened, must be wide enough to be put on over the head.

Two rings of this type have been found in Skåne. Both of them are heavier than the magnificent golden rings from Västergötland and Öland. One of these was found slightly more than one meter below the ground south of Höjeå at Trolleberg near Lund, while digging a ditch. (Picture 5) This golden ring has an outer diameter of $23.2 \mathrm{~cm}$ and a weight of $1.255 \mathrm{~kg}$. The other necklace of the same type was discovered at Ryd in the parish of Skabersjö, in connection with ploughing. Its diameter is $23 \mathrm{~cm}$ and its weight 967 gr., slightly smaller than the ring from Trolleberg (Strömberg 1963: 76-79).

At Bragnum in the parish of Floby in Västergötland another ring was found which is very similar to these two rings from Skåne. Its maximum inner diameter is $20 \mathrm{~cm}$ and its weight $827.7 \mathrm{gr}$. It is made of solid gold and decorated with crescent-shaped stamp ornaments. Montelius dates this ring to the second half of the fifth century A.D., as well as the two necklaces of the same type from Skane. As an argument for this he points out that several rings of this type have been found together with Roman and Byzantine solidi, i.e. gold coins from the fifth century, or together with other objects belonging to this time (Montelius 1912: 10). The largest Danish neck-ring of this type originates from Øland on Limfjorden. It weighs ca. $1 \mathrm{~kg}$.

The other type of neck-ring can be opened and is made of two thin golden bars. Several neck-rings of this kind are often found together. This is, for

\footnotetext{
${ }^{6}$ Concerning the ring from Hjallelse see Brøndsted 1938 and Munksgaard 1952. An almost exact counterpart to this ring, although made of bronze, was found in Malax in Finland. This ring, however, has no stamped ornaments. The Danish and Swedish rings are stray finds. Unlike to this, the necklace from Malax was found in a grave. Concerning the ring from Malax and other similar rings from Finland, see Kivikoski 1947: Taf. 30: 233, Taf. 31: 236.
} 
instance, the case with the find from Frær in Himmerland, Denmark, where five rings were discovered together.

\section{Discussion}

A great number of neck-rings have been found in the ground or in peatbogs. Several types of necklaces can be discerned. Their function has been a subject of discussion. Brøndsted is ambivalent between interpreting them as offerings to the gods or as hidden treasures. He points out that uncoined gold was the standard of value of this time, but he considers it most likely that the undamaged neck-rings should be understood as offerings (Brøndsted 1929: 67-68).

Holmqvist is more detailed in his interpretation of the three golden collars from Västergötland and Öland. He considers it possible to discern a programme in the construction of the necklaces, and he regards them as carriers of a message, expressed in pictures. It is, he claims, plausible that they "were made in a surrounding where astrological ideas were common and where magical opinions connected to runes and numbers played a crucial part in people's world-view, in fact in their way of living in general" (Holmqvist 1980: 98; my translation). Holmqvist points out that people in southern Scandinavia had good connections with the tribes of southern and western Europe, and he presumes that they were influenced by their conceptions. Hence, for the interpretation of the neck-rings we must take into account "not only the narrow Nordic aspect, but the spiritual current of the time as a whole" (Holmqvist 1980: 99; my translation). He further hints at the possibility that the collars were part of the priest's/king's equipment and that they might have been used as "a kind of shamanistic instrument, a counterpart to the troll-drums of the Laps" (Holmqvist 1980: 99; my translation). Holmqvist is of the opinion that the golden collars were worn by men, and he rejects the idea that they might have been used as women's jewellery.

In my opinion several reasons indicate that a number of neck-rings had a ceremonial function during the Migration Period. One reason is their often considerable dimensions. The diameters of the golden collars from Västergötland and Öland are, respectively, $19.5 \mathrm{~cm}, 21 \mathrm{~cm}$, and $22.6 \mathrm{~cm}$. The remaining fragments of the collar from Köinge indicate that it had a diameter of ca. $30 \mathrm{~cm}$. The ring from Hannenov measures $24-25 \mathrm{~cm}$, while the ring from Hjallelse has an inner diameter of no less than $36-37 \mathrm{~cm}$.

A further argument that the neck-rings from the Migration Period had a ceremonial function is the costly material, gold. A golden neck-ring repre- 
sented a fortune. For the gold alone needed to produce the Hannenov ring, with a weight of $526.3 \mathrm{gr}$., it would have been possible to buy 7.5 tons of wheat in the Roman empire during the fifth century. ${ }^{7}$ In order to understand the importance of this, one must keep in mind that agriculture was almost entirely manual, so that a certain amount of food required many times more work than today.

Many rings from this time are the work of a precise and extremely qualified goldsmith, and they have an overwhelming beauty. To a very great extent this applies to the golden collars from Västergötland and Öland, but they are not unique. Several other neck-rings are the result of a highly developed craftsmanship. In the presentation above I have offered many examples of this. The golden neck-rings are the results of very great investments, not only in raw material, but also in work expended.

The wooden sculpture from Rude-Eskildstrup supports the view that the neck-rings from the Migration Period had not only a ceremonial use in general, but also a sacred function, as this figure most likely represents a god. I shall give some arguments to support this view.

My first argument is that the wooden statue was found in a peat-bog. Bogs and wetlands were in prehistoric times used as places for cult, and they were often cult centres of whole regions for considerable periods. This is evident from the fact that great numbers of weapons of different kinds, jewellery, coins, tools, etc., from far different periods have been found in the same peat-bog. The objects have often been folded or torn to pieces, sometimes even damaged by fire.

Their locations sometimes indicate that they were thrown into the water from the same place on the shore. In this case they are lying together in a fan-shaped form. Sometimes they were dropped into the water from boats. In some cases the objects were sorted according to their function before being packed together in bundles and submerged. The custom of making offerings in bogs and wetlands can be found from the Neolithic Period and well into the Iron Age, reaching its peak during the Iron Age. For this reason finds from peat-bogs are usually interpreted as offerings. ${ }^{8}$

My second argument is that the wooden statue was placed standing in the bog. This indicates that the sculpture was considered to be or to repre-

\footnotetext{
${ }^{7}$ The Hannenov ring has a gold content of $84 \%$. One solidus, the Roman gold coin, had a weight of 4.55 gr. pure gold. Klindt-Jensen 1957, who gives interesting information concerning the economic circumstances in the Roman empire during the Migration Period, states that one could buy $78 \mathrm{~kg}$ of wheat for one solidus. See Klindt-Jensen 1957: especially 144 .

${ }^{8}$ Extensive research supports this view. For some examples, see Görman 1987: 131.
} 
sent the god who reigned over the place. It can hardly be interpreted as an offering.

The strange object, resembling a sack, which he holds on his knee constitutes a third reason to conceive this figure as a god. Scholars have found this object difficult to understand. I should like to point out, however, that this is precisely the way fertility gods were depicted in Central Europe during the first centuries A.D. An excellent example can be seen in picture 16, which represents the Celtic god Cernunnos with a similar sack in his arms. The sack, from which a stream of coins is flowing, is a symbol of fertility.

Thus, there are good reasons to believe that neck-rings had a sacred function during this period of time. But, as we shall soon see, this is not an innovation in the Migration Period, but is based on an older tradition.

As I have mentioned, the neck-ring has often been understood as a piece of jewellery and as a sign of dignity. This could be regarded as an understanding, which excludes the interpretation of it as having a sacred function. In my view, however, that would be an anachronistic way of transferring a modern interpretation of the relation between sacred and profane to past times. In our secularized environment, religion is often regarded as a separate sphere, distinguished from other parts of human life. This view deviates from the understanding of religion common in other times and societies. In past times questions people asked about life and death were expressed in religious beliefs and actions, and religion permeated all social life.

\section{Neck-rings from the Roman Iron Age (0-400 A.D.)}

\section{Skedemosse, Öland, Sweden}

Numerous of finds were made when Skedemosse, the largest fen on Öland, was excavated in 1959-1962 under the leadership of the Swedish archaeologist Ulf Erik Hagberg. The finds consist mainly of weapons of different kinds, and bones from animals and men, but the most impressive discovery was a gold hoard with a total weight of $1.3 \mathrm{~kg}$. This hoard consists of seven heavy golden rings, each weighing between $174.8 \mathrm{gr}$. and $204.5 \mathrm{gr}$. Six of these neck- or arm-rings were found within an area of 225 square meters. They are all of the same style, the snake-head type with profiled end knobs. The seventh ring, which was found earlier in the same area, is of a simpler kind. None of the rings show any traces of having been worn. For this reason Hagberg wonders whether they may have been produced for the 
purpose of being offered. A common trait of all these rings is that they have been exposed to deliberate damage. They have been rolled up and some of them show signs of fire. Consequently, the people who once offered these rings in the lake, which has in the course of time turned into a fen, first subjected them to the same violent destruction that characterizes many objects from the Bronze and Iron Age found in peat-bogs. ${ }^{9}$

Hagberg dates the neck- or arm-rings to the third or fourth century A.D., i.e. to the Roman Iron Age. The bulk of the finds, however, belong to the whole period from 200 to 500 A.D. This means that Skedemosse served as a place of sacrifice for a long time. Hagberg himself considers Skedemosse to be the holy place of a tribe where religious acts were performed continuously.

\section{Havor, Gotland, Sweden}

In 1961 the ring fort of Havor in Hablingbo parish in the south of Gotland was excavated. This fort is situated on the south shore of a former lake, now a peat-bog called Mästermyr. On the very first day of the excavation a sensational find was made in the inner part of the wall of the fort, built from mould and stones. In the wall a well kept bronze situla was found standing. It contained a large golden ring-a torc. (Picture 6) A torc is a Celtic neck-ring which is almost fully closed. In the situla were also found a wine ladle and a strainer, kept together with a leather strap, and below them a few drop-shaped bronze bells and three more wine ladles. Finally, a bronze ring was found, the function of which was not understood at first. At last, however, it was realized that the bells had been fastened to the bronze ring with strong leather straps. Together they had formed a kind of rattle. Most of the bronze objects originate from the Roman area or from the Roman provinces.

The gold ring itself has a diameter of slightly more than $24 \mathrm{~cm}$. Its two end knobs, each with a diameter of five $\mathrm{cm}$, are united with an ingenious locking device. Adjacent parts are covered with abundant ornaments in filigree and granulation technique. Each end section is decorated with stylized cow or bull heads, face to face with each other.

Erik Nylén, who was the archaeologist responsible for the excavation, dates the golden torc to the years around the beginning of our chronology, or slightly later. And further, he finds it credible that it was produced in the Black Sea region. His main argument for this is the fact that three very

\footnotetext{
${ }^{9}$ The finds from Skedemosse are described and discussed in Hagberg 1967, the golden rings above all in Hagberg 1967/1: 52-53 and Hagberg 1967/2: 9-12.
} 
close counterparts to the ring from Havor are known from southern Russia. Two of these originate from a hoard in Kiev, and one of them from a grave in Olbia. However, he does not want to exclude the possibility that the Havor ring is of Nordic origin.

Nylén interprets the remarkable find as a temple hoard, i.e. articles of great value belonging to a temple. In connection with this he emphasizes that our knowledge of the former function of the ring forts is very limited. They may very well have been used both as havens of refuge and as places for cult. Counterparts to the rattle are known from the Roman province, where they were used in the cult. The large gold ring shows no traces of wear. This fact, together with its size, its material, and the circumstances under which it was found, indicates that the gold torc once had a sacred function. Nylén himself considers it to have been an adornment for a god (Nylén 1962: 94-111; Nylén 1967-68: 50-52).

The find from Havor originates from the first part of the Roman Iron Age. The gold hoard from Skedemosse dates to the second part of the Roman Iron Age. Many other abundant finds of golden objects, dating from the Roman Iron Age, have been made in southern Scandinavia, mainly on current Swedish territory, although the greatest number of golden finds have been dated to the Migration Period. ${ }^{10}$

\section{Neck-rings as divine attributes on some cauldrons}

\section{The cauldron from Gundestrup, Jylland, Denmark}

Several neck-rings of the same type as the rings from Havor and Dronninglund, ${ }^{11}$ i.e. torcs, are found on the enormous silver cauldron from Gundestrup in Vesthimmerland. (Picture 7) Like the torcs this cauldron is now generally dated to the years around the beginning of our time. However, there has been great disagreement on this matter, and different scholars have dated it from the third century B.C. to the third century A.D.

The Gundestrup cauldron, which has a diameter of ca. one meter, was found in a small peat-bog called Rævemosen. Once it had been placed there quite openly on a strong moss surface, after having been divided into pieces. It consists of a number of silver plates, with chased, partly gilded busts of Celtic gods and goddesses, and pictorial scenes, probably repre-

\footnotetext{
${ }^{10}$ Many other examples of golden necklets from the Roman Iron Age are described by Stenberger 1964: 417-420 and Brøndsted 1960: 195.

${ }^{11}$ The ring from Dronninglund is discussed below under the heading "Necklaces from the Pre-Roman Iron Age".
} 
senting offerings. As many as ten of the gods wear torcs. In addition, one of these gods, Cernunnos, is holding a torc in one of his hands. One of the goddesses is wearing a neck-ring which almost completely corresponds to the above mentioned ring from Olbia. This ring is a close counterpart to the torcs from Havor and Dronninglund.

The place of origin of this silver bowl has been the subject of discussion, as has its dating. Some scholars have looked for its origin in the eastern part of the Celtic area, others in the western part. ${ }^{12}$ It has also been argued that the cauldron could have been produced in Scandinavia, by Sophus Müller as early as 1892 (Müller 1892: 61), and later by Erik Nylén. The latter argues that the cauldron is a local product, created by Thrakian silversmiths in the Celtic style. To support this interpretation he points to a number of finds from Denmark and Sweden of similar cauldrons, as well as face masks and statuettes made by a similar technique and style (Nylén 1967-68: 133-166).

\section{The cauldron from Rynkeby, Fyn, Denmark}

A vigorously modelled female head, surrounded by two bull heads, is reproduced on another large bronze cauldron from Rynkeby. (Picture 8) It is generally understood as a goddess. This vessel was once placed on a strong surface in Illemosen, a peat-bog near Rynkeby on the island of Fyn. As time went on, it sank into the bog. Before it was set out on the moss it was divided into pieces, but it is estimated to have had a diameter of ca. $70 \mathrm{~cm}$ and held ca. 600 litres (Müller 1933: 42-44; Albrectsen 1990; Mortensen 1991: 375).

\section{Discussion}

In Skedemosse weapons, coins, and pearls have been found, as well as many other things. The bulk of the findings, however, consists of several tons of animal bones. This indicates that great numbers of animals were offered to the gods on this place. Skedemosse has become famous, above all because the Skedemosse finds are the biggest collection of gold ornaments ever found in Sweden.

Skedemosse is strategically situated on the centre of the isle of Öland. There is good reason to understand it as the central holy place of a whole district, as Ulf Erik Hagberg does. Consequently, the expensive neck-rings

\footnotetext{
${ }^{12}$ An origin in the eastern area is advocated, for instance by Drexel 1915, and in the western area, for instance by Arbman 1948 and Klindt-Jensen 1961.
} 
should probably be interpreted as offerings. This interpretation is also supported by the destruction they have been exposed to.

With no doubt I can agree with Erik Nylén, who understands the find from Havor as a treasure belonging to a temple. The size of the ring, its material, as well as the magnificent handiwork, indicate its sacred use. Its size is remarkable, as it is a torc. Characteristic of such rings is that they were worn tightly fitting round the neck. Even the circumstances around the finding support a religious interpretation.

The silver cauldron from Gundestrup is decorated with a number of gods and goddesses. There is general agreement that these busts represent a Celtic pantheon, with one of them depicting a god with the same attributes as the Celtic god Cernunnos. He is characterized by his sitting pose, by his antlers, and by the snake with the head of a ram. He is wearing a torc around his neck and he is holding another one in his hand. This picture of Cernunnos indicates that the torc was a divine attribute in the Celtic world at this time.

It is a matter of discussion whether these cauldrons are local products or imported objects. If they were produced in Scandinavia, they may represent local deities. If they are imported objects or produced by imported foreign craftsmen, they may represent gods worshipped on the continent. In any case they were used here in religious rites.

To sum up: During the Roman Iron Age neck-rings were used as offerings. There is also good reason to believe that during this period they were used as divine attributes. This interpretation is supported by the busts of deities on the vessels from Gundestrup and Rynkeby, who are provided with torcs, and by the ring from Havor.

Now, did the neck-ring have a religious use during the previous period, i.e. the Pre-Roman Iron Age, as well?

\section{Neck-ornaments from the Pre-Roman Iron Age (500 B.C.-0)}

\section{Dronninglund, Vendsyssel}

One single neck-ring of the same kind as the Havor ring was found in a peat-bog near Dronninglund in Vendsyssel, ca. $0.9 \mathrm{~m}$ below the ground. (Picture 9) The ring from Dronninglund is a torc, with a diameter of $16 \mathrm{~cm}$ and a weight of 613 gr. Like its later counterpart from Havor, it is made of gold with hollow end knobs, but unlike the Havor ring, it is solid. The locking systems of the two rings are similar, but the decoration techniques are slightly different (Müller 1900: 140-143; Brøndsted 1960: 73-74). 
Sophus Müller believes the origin of the Dronninglund ring to be southern Russia, with reference to a similar find from Smyela close to Kiev, and another from Olbia on the Black Sea (Müller 1900: 142).

\section{Smederup, Jylland, Denmark}

The torc from Dronninglund belongs to the Pre-Roman Iron Age. From this time originates also the large find of rings from Smederup Mose, five $\mathrm{km}$ south-east of Odder on Jylland. (Picture 10) This little peat-bog, covering an area of not more than $80 \times 200 \mathrm{~m}$., is a typical bog used for offerings. In 1942 a few farm-hands were digging out peat in this bog, when they found some standing boards. It appeared that they were part of a well, made from robust oak planks. The well was filled with small stones and potsherds from 14 pots. The find has been dated to the early Pre-Roman Iron Age. A few years later a find of more than 300 bronze rings was made close to this well. These rings are neck-rings, arm-rings, and loop rings. Most of them have been well kept, although some of them show signs of fire. Two neck-rings were bent together and fastened to each other being put down in the bog.

These two finds from Smederup are regarded as offerings. The objects seem to belong to the same period, but it is unclear whether they were laid down on one and the same occasion. A similar find, consisting of ca. 120 thin neck- or arm-rings, has been discovered in a peat-bog called Sattrup Mose, only about $30 \mathrm{~km}$ from the Smederup find. ${ }^{13}$

\section{Neck-rings with reversed twist}

A common form of neck-ring during the first part of the Iron Age as well as the latest part of the Bronze Age is a twisted ring, where the twist is reversed several times (Oldsager 1979: 207). These rings were worn in pairs and they are often found in pairs. The fact that they are found in pairs proves that these ornaments are not lost properties but deliberate offerings in lakes and bogs.

One find of this type of neck-ring originates from a Danish peat-bog called Hallenslev Mose at Høng on the island of Sjælland. Two rings with reversed twist were found lying above each other, ca. one meter down, close to the border of the large bog. Distinct marks of wear indicate that they were carried together (Müller 1917: 162-163).

\footnotetext{
${ }^{19}$ Concerning the finds from Smederup and Sattrup see Vebæk 1944: 21-28.
} 
The majority of these sometimes very heavy neck-rings with reversed twist were worn, but pure votive rings have also been found. The fact that they are not intended for wearing is evident, as they cannot be opened, while they are too small to be put on over the head, even for a half-grown person. It is a common interpretation that they were produced only for the purpose of being offered (Brøndsted 1958: 237; Müller 1917: 165-166).

Another common type of ring from the Pre-Roman Iron Age is the torc with ball shaped terminals. Its end knobs are decorated in Celtic style, with small bulges or triangular motifs. Neck-rings of this type have been found in eastern Denmark, in southern and central Sweden and in Norway. In the central parts of Sweden they have been found in graves, while especially on Danish territory they have been discovered in peat-bogs (Kaul 1991: 540).

\section{Discussion}

From the Pre-Roman Iron Age a number of neck-rings have been found, which evidently were offered. This proves that sacrifices of neck-rings were no innovation during the Roman Iron Age but existed in Pre-Roman time as well. Some finds from the Pre-Roman Iron Age are characterized by their large number of rings. This is typical of the finds from Smederup and Sattrup, and it distinguishes the Pre-Roman period from later periods. From this time as well as in later periods we find neck-rings which were evidently not intended to be worn. They might instead have been produced in order to be used in the cult.

But when did this custom of laying down neck-rings as offerings begin?

\section{Neck-rings from the Late Bronze Age (1000-500 B.C.)}

In the Late Bronze Age it was a custom for women to adorn themselves with collars. During the middle period of the Bronze Age these collars were replaced by neck-rings. At the end of the Late Bronze Age the neck-ring is the dominating object in the finds.

To begin with, a neck-ring was made up of a simple twisted or ribbed bronze rod, but it was soon made larger and heavier. It was held together by hooks in the ends. During the Late Bronze Age these ends grew larger and became plates, decorated with geometric ornaments and figures of the 
same kind as those occurring on contemporary razors and on rock-carvings. The ends of the plates were turned into a spiral form. ${ }^{14}$

The reversed twist is another design, characteristic of neck-rings from the Late Bronze Age. (Picture 11) It is possible to observe a development even in these rings, from slender rings of regular thickness and a uniform twist, via heavier rings with a reversed twist, to the so called Wendel rings. These rings, with elevated, sharp ridges and a reversed twist, were used into the Pre-Roman Iron Age. Signs of wear indicate that several of these rings were worn together, one resting on the other.

Thus, the neck-ring was used occasionally as an ornament in the Early Bronze Age. During the middle period of the Bronze Age it became more frequent, at the expense of the older type of collar. In the Late Bronze Age it became more and more frequent, as indicated by the finds in ground and bogs. Usually they are found in pairs. ${ }^{15}$

In his book Helleristninger $i$ Danmark the Danish archaeologist P V Glob reasons about the Danish sacrificial finds from the Late Bronze Age. He notes that the neck-rings constitute $23 \%$ of the finds in the fourth period, $53 \%$ in the fifth period, and no less than $94 \%$ in the sixth period (Glob 1969: 198-199). More than 70 offerings containing neck-rings, including more than 200 rings altogether, are known from southern Scandinavia (Stenberger 1964: 302). Most of these finds have been discovered in bogs and streams.

Glob, as well as many other scholars, makes the interpretation that a goddess with the neck-ring as her prime symbol comes to the forefront during period VI of the Bronze Age. (Picture 12) The small statuettes from this time, representing a naked woman, wearing only a neck-ring, have been interpreted as pictures of this goddess. The figures are only $10-12 \mathrm{~cm}$ high, and their neck-rings can be single, double, and sometimes even manifold. Her arms are bent, with the hands held over her bosom in a position indicating a mother goddess. Some scholars have assumed that these small bronze figures were simple copies of larger wooden idols, now lost (Bjørn

\footnotetext{
${ }^{14}$ The fact that these motifs are found on rock-carvings and razors is interesting. According to a current view the pictures on the rock-carvings are connected to religious ideas and rituals. See Görman 1987 and the literature quoted there.

The concentration of razors in the Late Bronze Age is striking. They can be found even in women's graves. For this reason it has been assumed that the razors had not only a practical use, but also a religious function, and that they were in some way included in the rituals around death. See Hyenstrand 1968: 185-189.

${ }^{15}$ Concerning the development and use of the neck-ring during the Bronze Age see Broholm 1943-49.
} 
1926: 42-44). Statues have occasionally been found in the ground and are generally dated to the latest part of the Bronze Age. ${ }^{16}$

\section{Discussion}

Offerings of neck-rings no doubt increased considerably during the latter part of the Bronze Age, and the deposits containing both male and female objects were gradually replaced by neck-rings. Usually they were deposited in pairs, but sometimes individually or three together. Women used to wear two neck-rings during the Bronze Age, and hence it is natural to believe, like Glob and others do, that the sacrifices of neck-rings were directed at a goddess with a double neck-ring as her symbol. Contrary to Glob, however, I should like to raise the objection that even men used to wear neck-rings during the Bronze Age, in this case single rings. Consequently, the ring offerings cannot be interpreted exclusively as offerings to a goddess with the neck-ring as her special attribute. Single rings may have been offered to a male god with the neck-ring as his attribute. Three rings together may have been intended for a pair of gods. This remains, however, to be proved.

People during the Bronze Age used the neck-ring as an ornament, at first on a very limited scale, and gradually more and more frequently. At the end of the Late Bronze Age neck-rings dominate the finds from ground and bogs. What can the reasons for this change have been? One possibility might be that a new religious significance was attributed to the neck-ring. Another explanation could be that existing religious connotations gained impact. A third reason might be that the cultic expression of religion changed. I have myself argued that new religious rites and conceptions, proceeding from Central Europe, exerted influence in southern Scandinavia during the Late Bronze Age (Görman 1987).

\section{Conclusions so far}

The custom of laying down neck-rings as offerings in the ground and especially in bogs and streams was a continuous habit in southern Scandinavia from the Late Bronze Age until the Migration Period, i.e. a time span of more than a thousand years. At the end of the Late Bronze Age and in the Migration Period, the frequency of these sacrifices increased.

${ }^{16}$ The finds from Fărdal at Viborg and Grevensvænge at Næstved, both containing neck-rings, are other Danish finds from the Late Bronze Age that have been interpreted as sacrifices. Concerning the Fårdal find see Kjær 1927 and Glob 1969: 191-193. Concerning the find from Grevensvænge see above all Djupedal \& Broholm 1952. 
The form and decoration of the neck-rings changed during this long time span. It is possible that these changes reflect the different taste of each time. But there is also a continuity: the neck-ring was used as an offering, i.e. donated as a sacrifice to one or more gods. At some times it was a symbol of the god itself, used to decorate his or her idol, to indicate his or her presence, etc.

\section{Neck-rings in Central Europe}

During the Hallstatt and La Tène Periods neck-rings were in frequent use on Celtic territory in Central Europe. Men and women adorned themselves with torcs, which sometimes even followed them into their graves. Both men and women used neck-ornaments, which is evident from finds in graves. They made deposits of neck-rings, one by one or several together, in the ground and in peat-bogs. It is well known that the torc had an important sacred function among the Celts. ${ }^{17} \mathrm{I}$ am going to illustrate this fact by a few examples from the Hallstatt and La Tène Periods. Karl Hauck has given evidence that the neck-ring continued to have similar functions even later, above all in the period 300-600 A.D. on Germanic territory on the continent (Hauck 1954).

During the Hallstatt Period the torc was a common burial gift in wellequipped men's and women's graves, especially the latter. Such graves from Hallstatt D (600-475 B.C.), containing gold torcs, are known from Eberdingen-Hochdorf, Ludwigsburg in Baden-Würtemberg and Vix in Burgundy (Collis 1984: 93-97).

Somewhat later, from the La Tène Period, are the graves from Rheinheim and Waldalgesheim in southern Germany. The costly grave goods contained several golden neck-rings (Moreau 1958: 124, Collis 1984: 128129). From 400 B.C and on, graves as well as grave goods became more stereotyped, and neck-rings are more uncommon even in female graves (Collis 1984: 130).

Neck-rings are also found deposited in the ground alone or several together. At Elgin in Scotland as many as three dozen twisted neck-rings of the type common in the Late Bronze Age have been found (Walker 1857). Several finds of gold torcs have been discovered in Snettisham, Needwood Forest, and Ipswich in England. (Picture 13) The first-mentioned find also

\footnotetext{
${ }^{17}$ Concerning the occurrence and use of the torc on Celtic territory, see Moreau 1958, Ross 1967, MacCana 1970, Collis 1984 and Green 1989.
} 


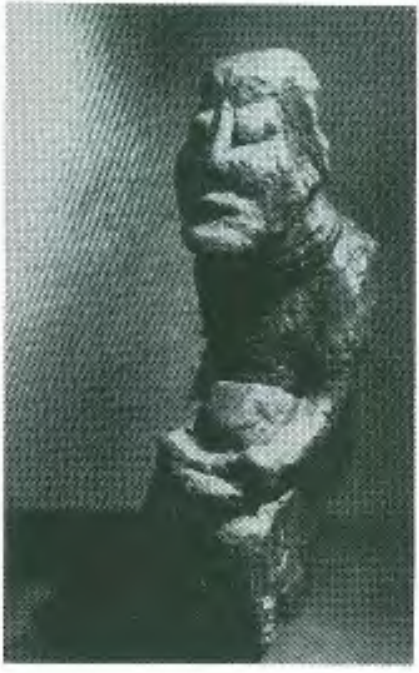

Fig. 1. Wooden sculpture with a trisected neck-ring from RudeEskildstrup, Denmark. Ström 1967: 155.

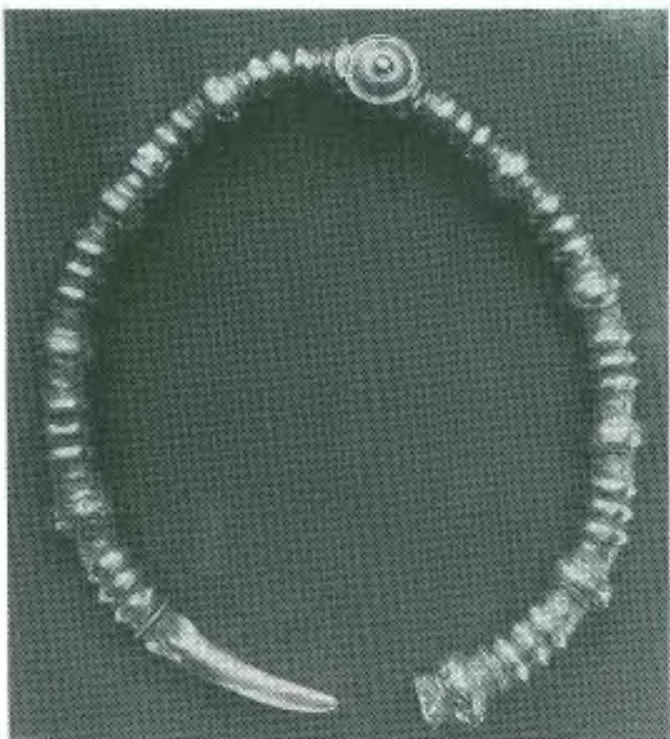

Fig. 3. Gold neck-ring from Hannenov, Falster, Denmark. Holmqvist 1980: 16.

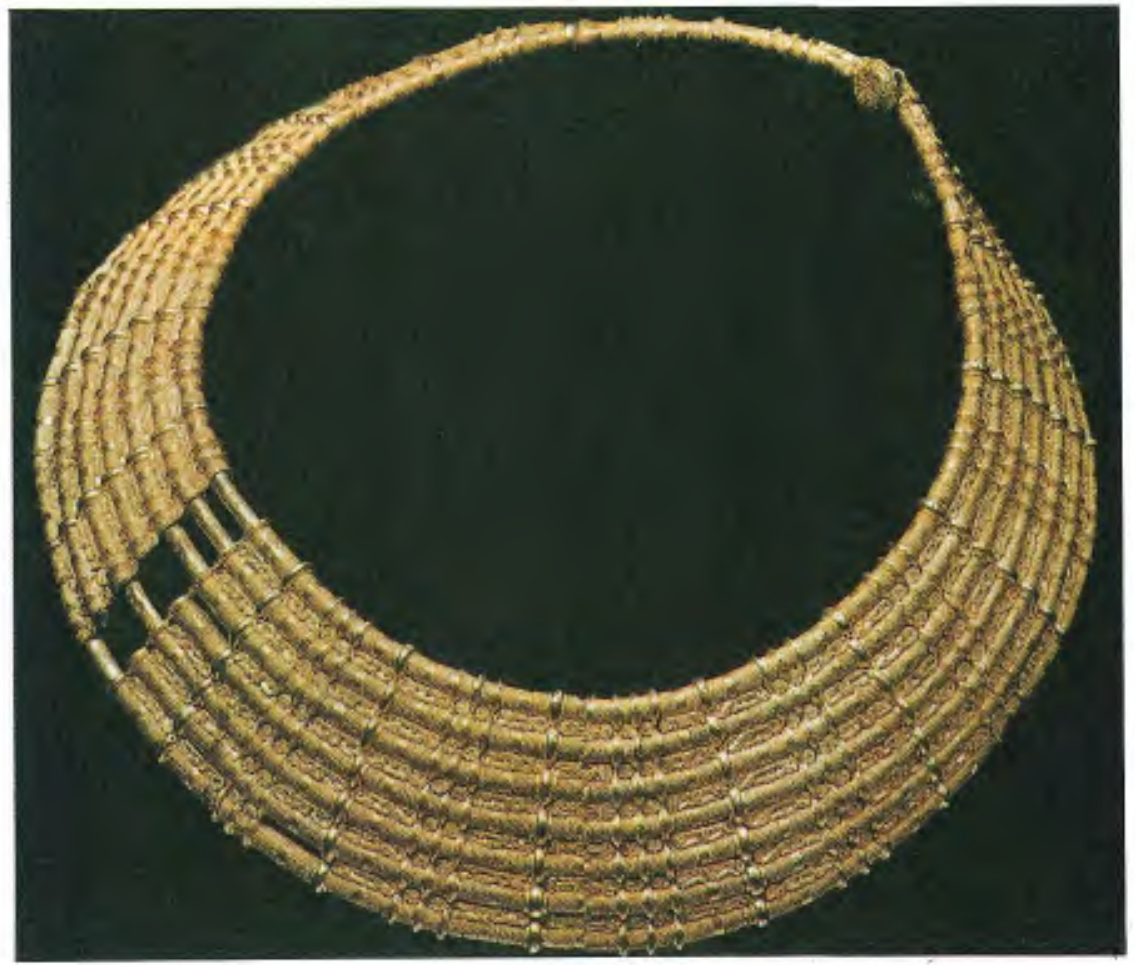

Fig. 2. Golden collar from Möne, Västergötland, Sweden. Holmqvist 1980: colour appendix 4 . 


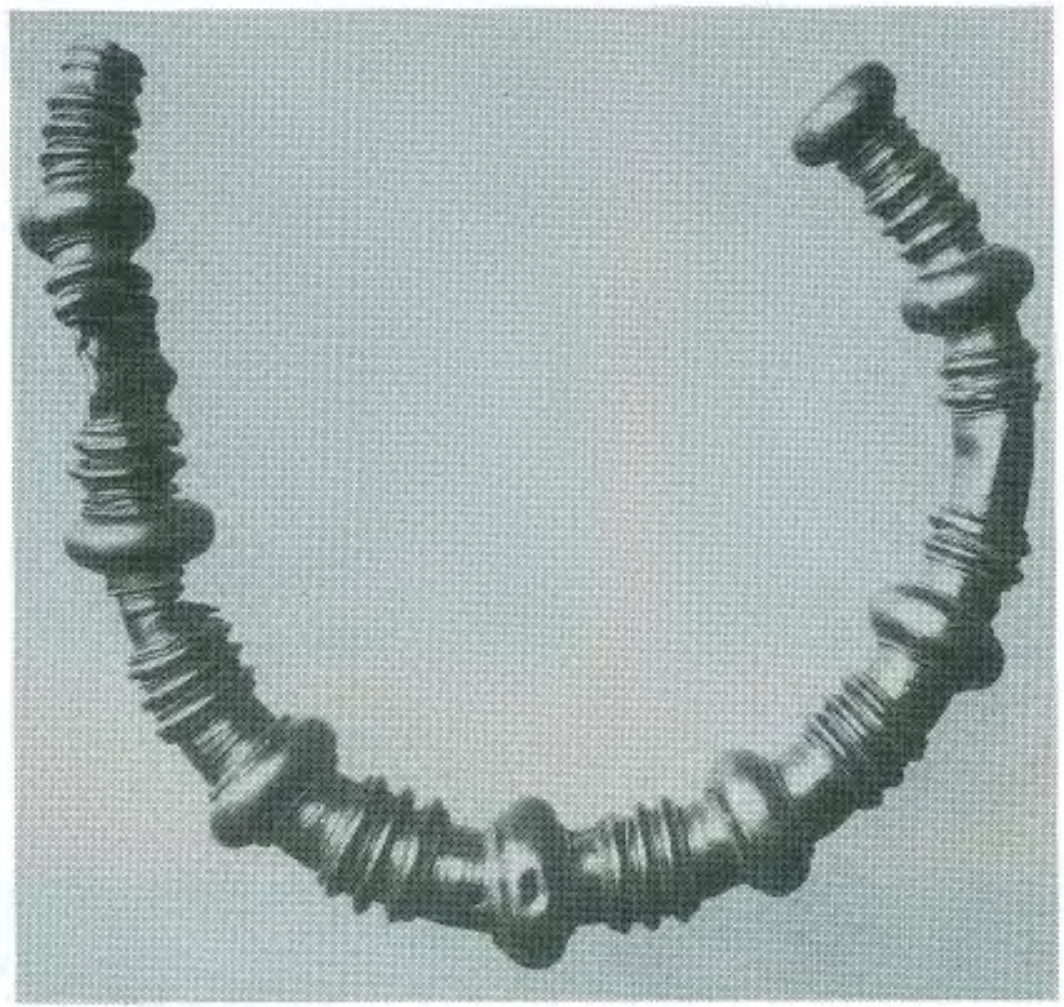

Fig. 4. Gold neck-ring from Hjallelse, Fyn, Denmark. Holmqvist 1980: 15.

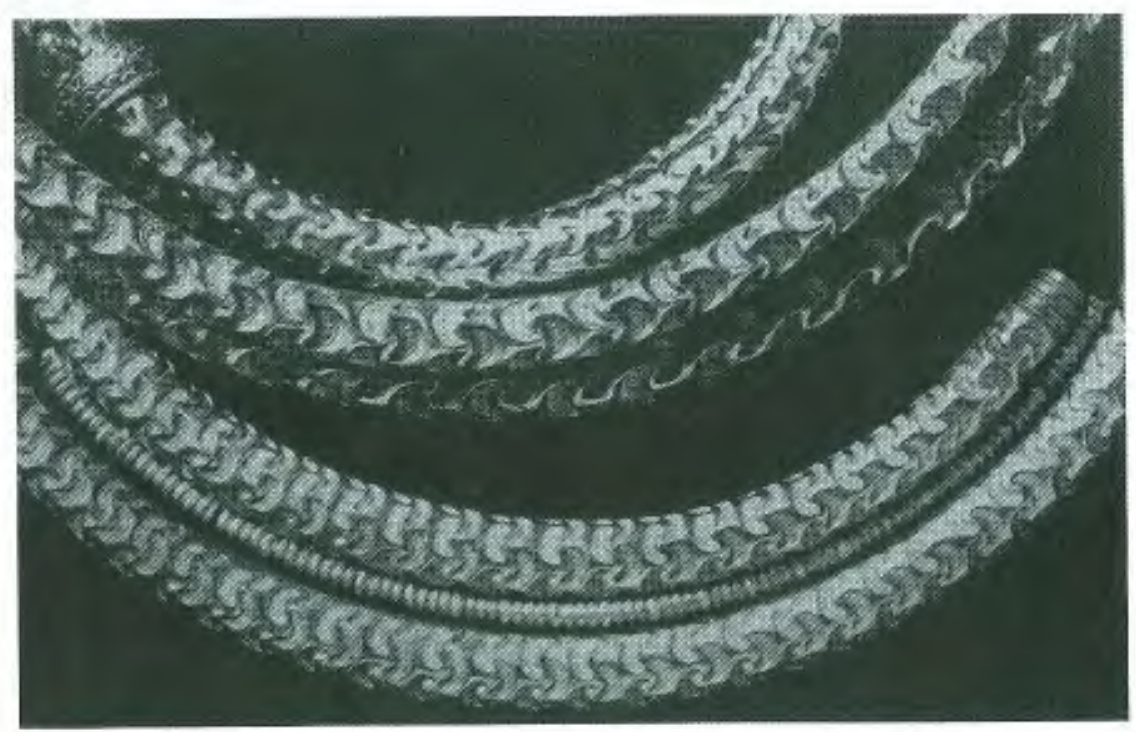

Fig. 5. Three golden neck-ornaments from Sweden, the one at the bottom from Trolleberg, Skåne. Holmqvist 1980: 18. 


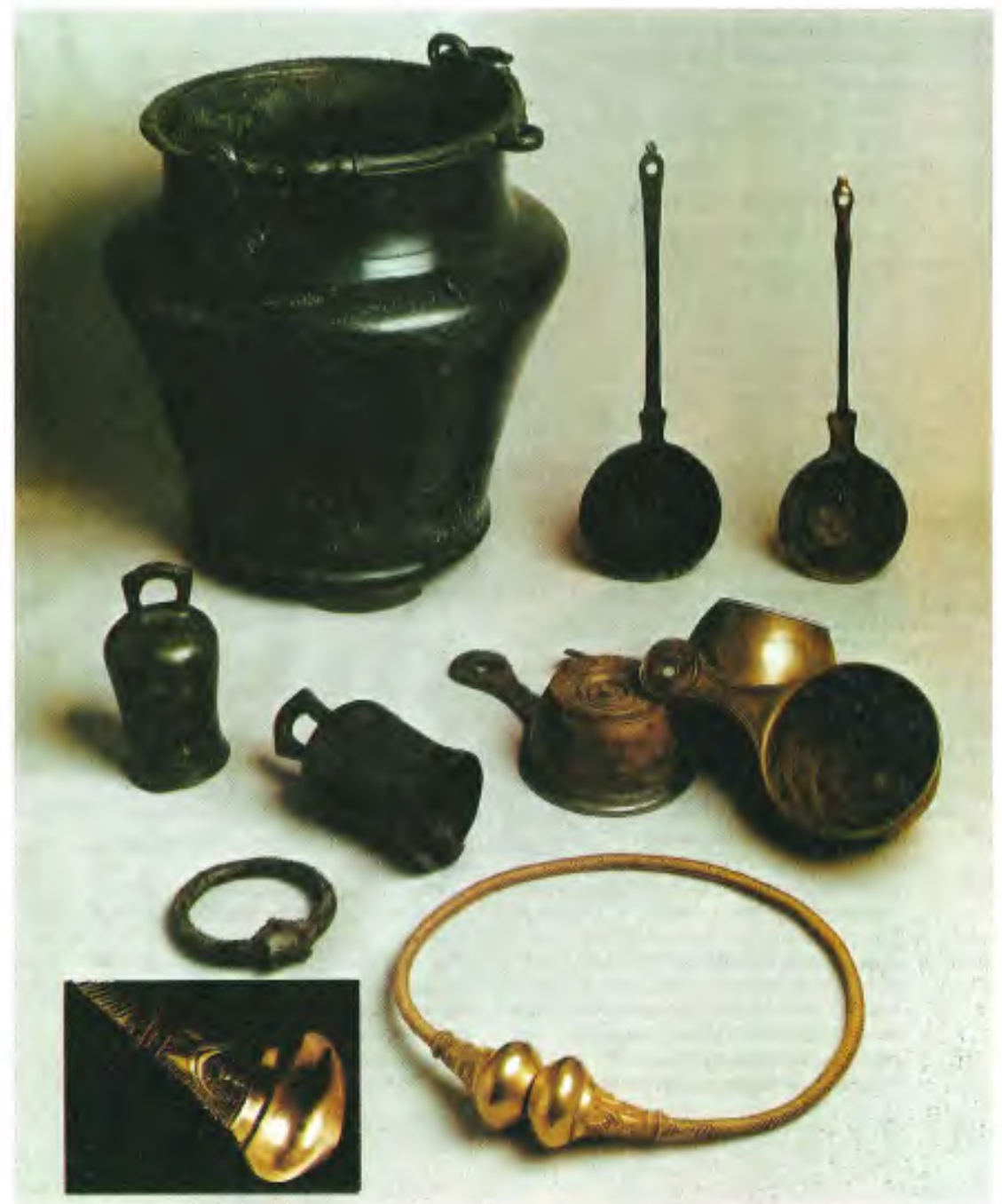

Fig. 6. The hoard from the ring fort of Havor on Gotland, Sweden Sweden. Burenhult 1991: 37.

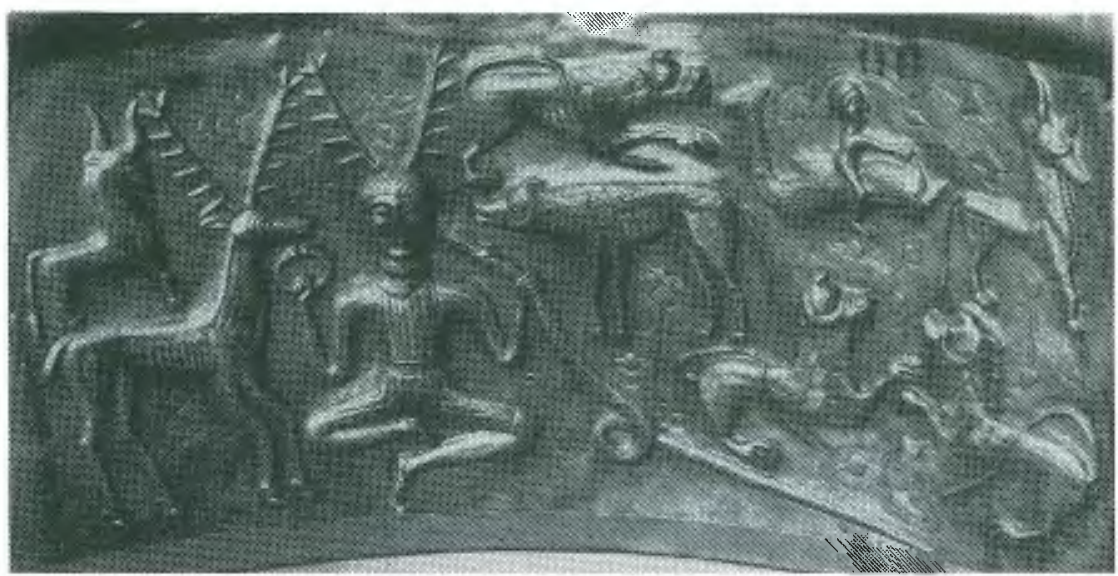

Fig. 7. God with torc (Cernunnos) on the cauldron of Gundestrup, Denmark. Klindt-Jensen 1961: 8. 


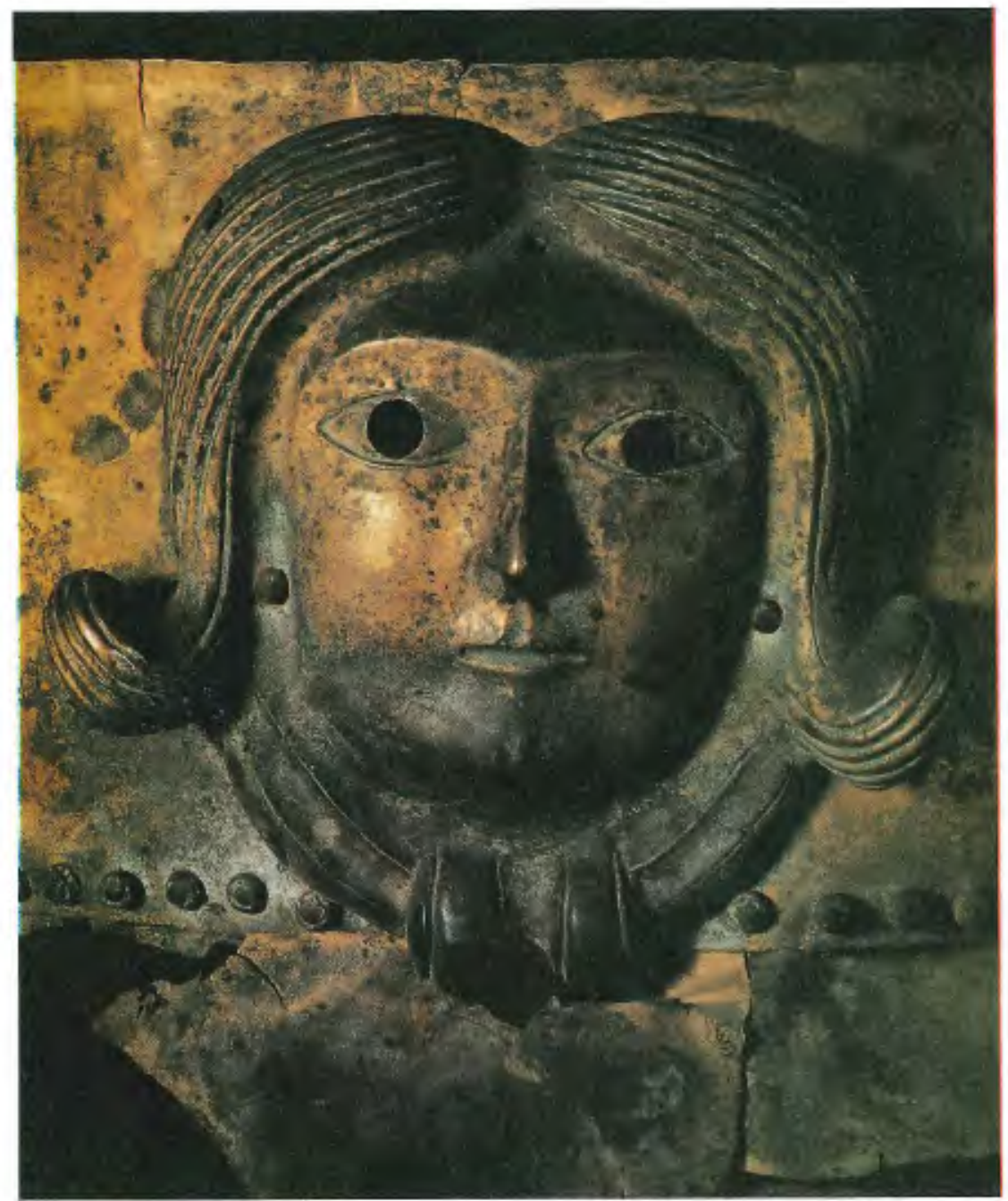

Fig. 8. Goddess with torc on the cauldron of Rynkeby, Denmark. Albrechtsen 1990: 99.

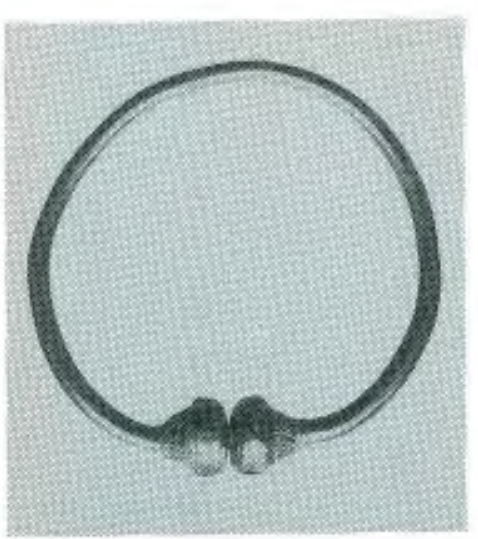

Fig. 9. Gold torc from Dronninglund, Jylland. Vebæk 1944: 24.

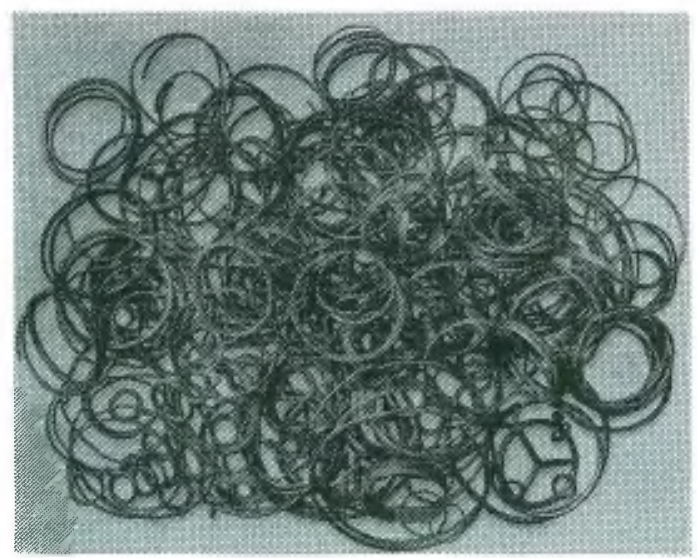

Fig. 10. Find of more than 300 bronze rings from Smederup, Denmark. Brøndsted 1960: 73. 


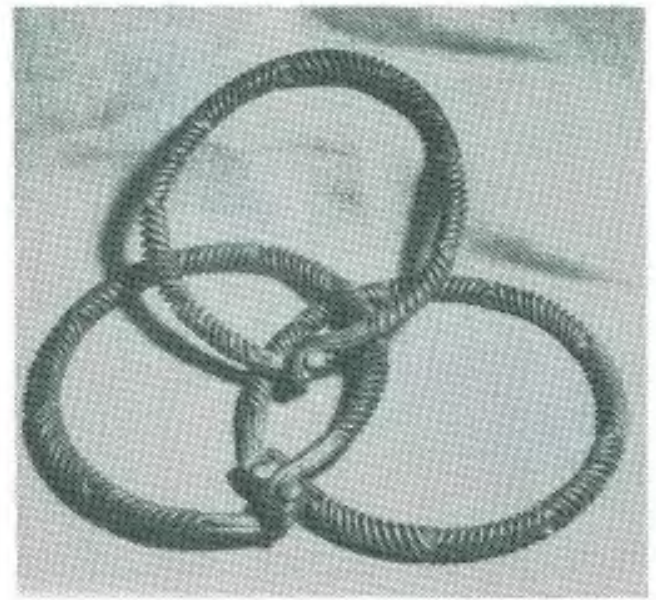

Fig. 11. Three neck-rings with reversed twist from a Swedish bog. Stenberger 1964: 300.

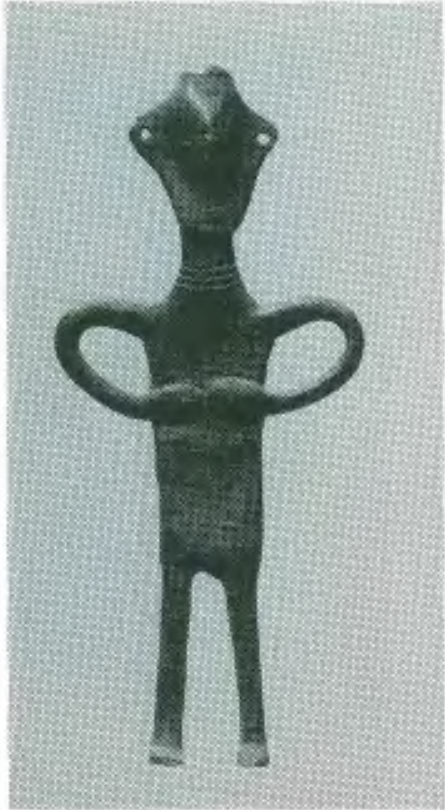

Fig. 12. Female bronze figure with a double neck-ring from the southern part of Sweden. Stenberger 1964: 299.

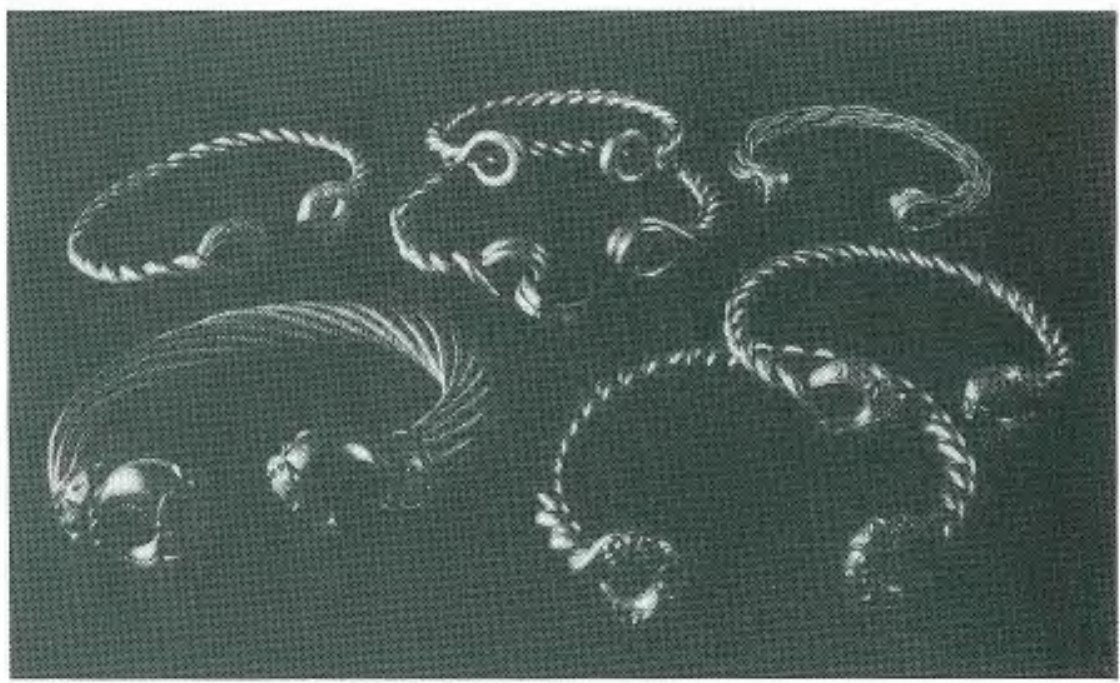

Fig. 13. Gold tores from Ipswich, Snettisham, and Needwood Forest, England. Raftery 1991: 568. 


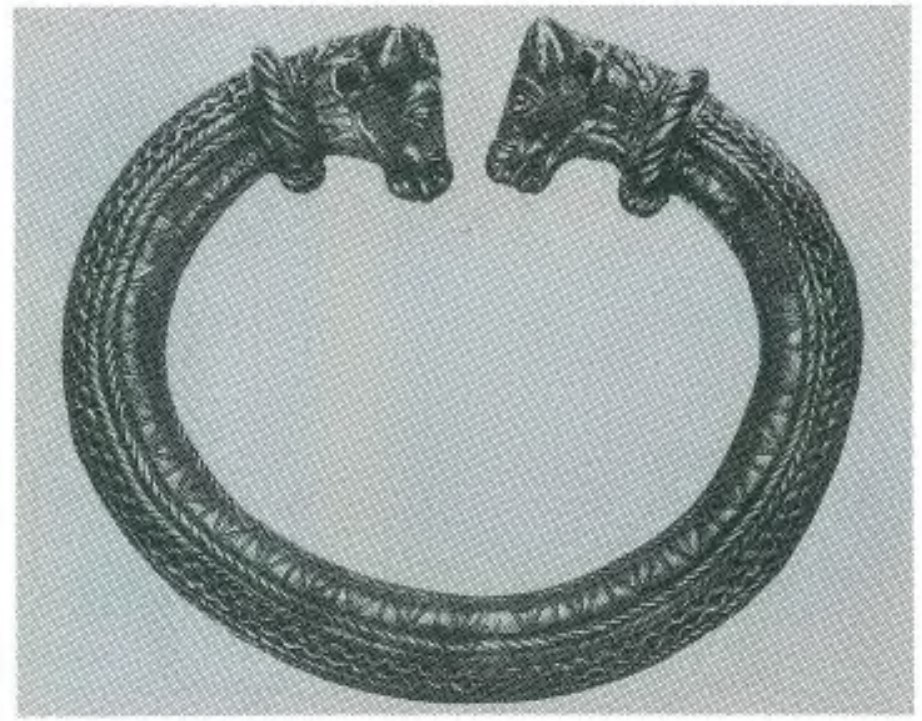

Fig. 14. Silver torc from Trichtingen, Germany. MacCana 1970: 65.

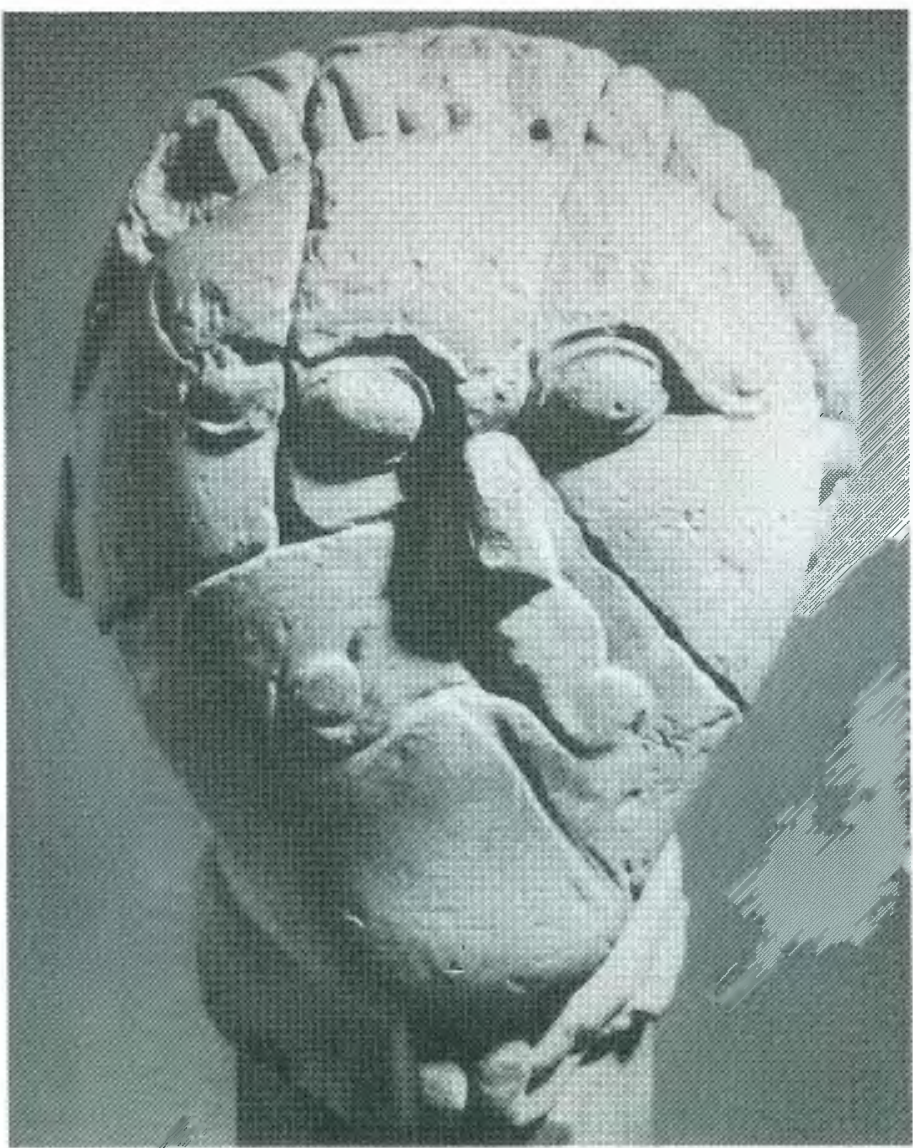

Fig. 15. Head of a god with torc from Msěcké Žehrovice, Bohemia. Duval 1991: 28. 


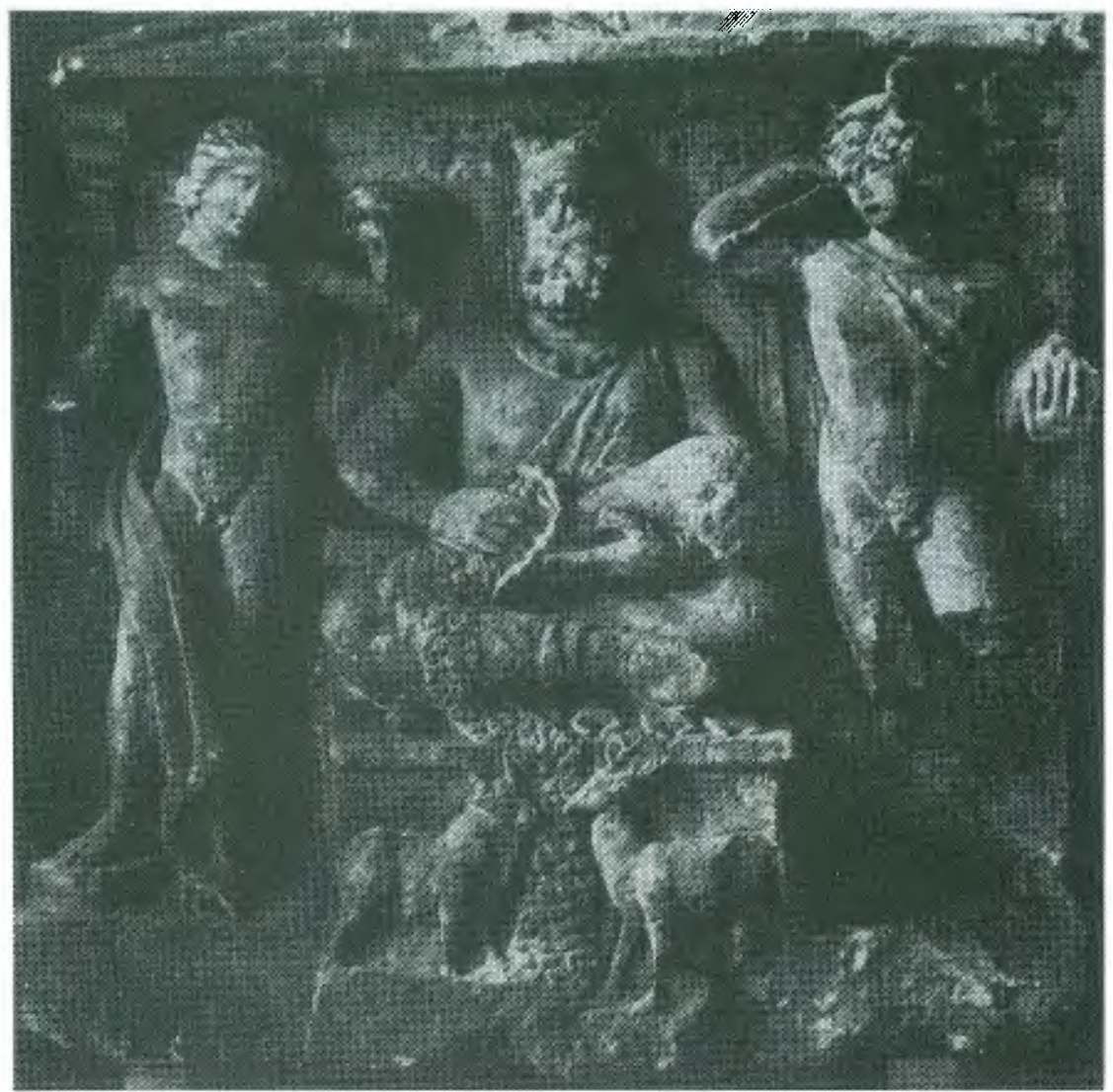

Fig. 16. Cernunnos with torc and a sack from which round objects, coins, are flowing. The relief is from Reims, France. MacCana 1970: 43. 


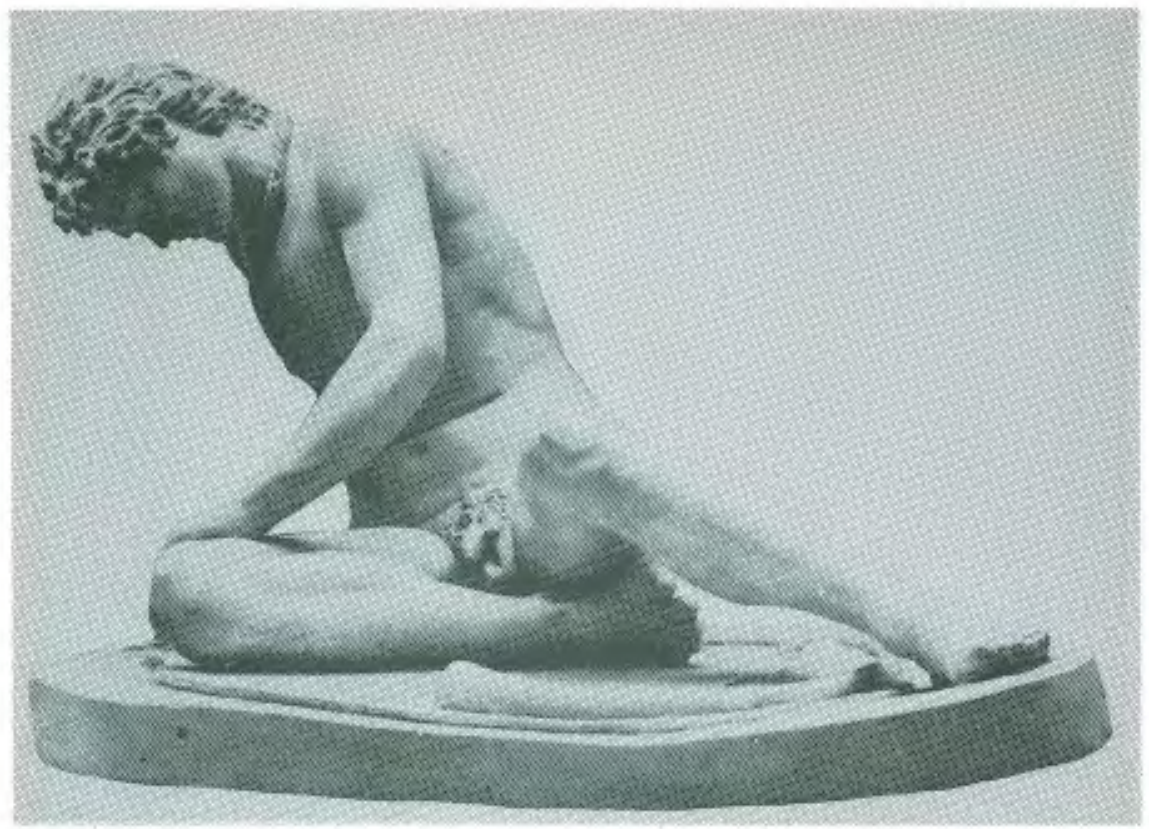

Fig. 17. The "Dying Gaul", MacCana 1970: 100.

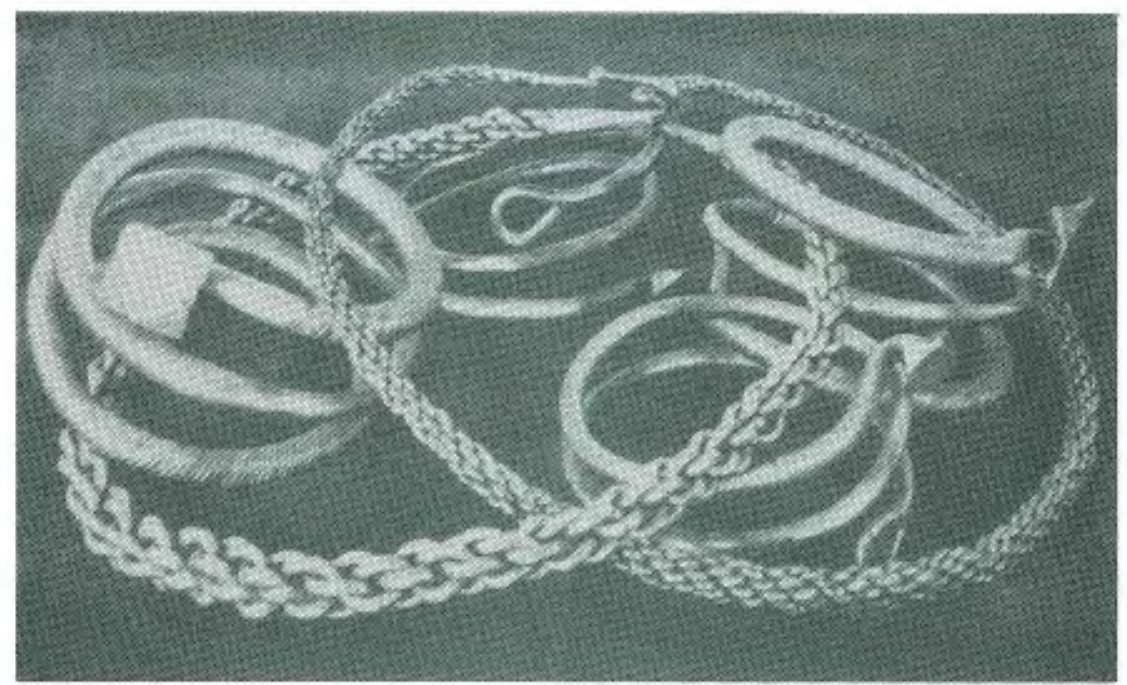

Fig. 18. Silver hoard from Öland, Sweden, containing twined neck-rings. Stenberger 1964: 725 . 
contained coins, by means of which it can be dated to ca. 50 B.C. The details of these findings are unknown (Collis 1984: 161-162). At Ersfeld in Switzerland four amply decorated gold torcs from the early La Tène Period were found under a large stone, together with a few arm-rings (Collis 1984: 118-119).

In 1928 an enormous torc was found at a depth of ca. $60 \mathrm{~cm}$ during draining work at Trichtingen in the Black Forest in Germany. (Picture 14) This ring is oval, its maximum outer diameter being $29.4 \mathrm{~cm}$ and it weighs $6.744 \mathrm{~kg}$. It consists of an iron kernel, coated with silver, equipped at each end with a bull head, which is in turn carrying a torc. Goessler, who described and discussed this find in 1929, considers the neck-ring to be a Celtic product from the northern part of the Balkans. He considers it credible that the torc was produced in the second half of the second century B.C. and intended for a god. Its size as well as its weight should indicate this. He sums up:

Der Ring ist als ein Votivring für einen Gott im Donau-balkankreis bei den Kelten entstanden und ist dann die Donau heraufgenommen ... Seine weiteren Schicksale auf dem Boden der Fundheimat liegen bis jetzt im Dunkeln. (Goessler 1929: 36)

Two neck-rings, probably with the same function as the Trichtingen ring, originate from a Celtic cult place in Libenice at Kolín in Bohemia. These rings are made of twined bronze thread, and they were found close to a few pole holes with rests of wood. The excavators, B Soudský and A Rybová, believe that the pole holes with wooden pieces are the remains of two wooden poles which once constituted idols, and around which the neckrings were hanging. It is estimated that this cult place was used during the La Tène Period, above all during the fourth century B.C. (Filip 1970: 6371).

At another cult place in Msěcké Žehrovice in Bohemia, a man's head of stone equipped with a torc was found in 1943. (Picture 15) This head was found in a $80 \mathrm{~cm}$ deep pit, together with animal bones and potsherds from the La Tène Period. The circumstances at the find indicate, according to Filip, that the head was once placed on a pedestal, serving as an object of cult on this holy place. Filip suggests that the head was knocked from the pedestal and thrown into the pit when the cult place was destroyed during the last century B.C. (Filip 1970: 71-73).

Celtic gods as well as goddesses are depicted with torcs. Usually they are wearing a torc around their neck, and sometimes they are holding yet another torc in the hand as an attribute. A large number of examples can be 
found ${ }^{18}$ This means that the torc is a frequent attribute of Celtic deities. To a specially high degree it is a characteristic of Cernunnos, who is regularly reproduced with at least one, and often several, torcs (Green 1989: 87-96). (Picture 16, compare also picture 7)

In Greek-Roman sculpture, Celtic warriors were also portrayed wearing neck-rings. These were probably regarded as a sign of dignity. The most famous sculpture is the "dying Galatian", a dying Celtic warrior naked except for his torc. (Picture 17) Attalos I of Pergamon had this statue raised in the third century B.C. to commemorate the victory he himself and Eumenes II had won over the Celts in Asia Minor (Rankin 1987: 208-209).

To sum up: On Celtic territory in Central Europe, neck-rings are found in graves, principally from the Hallstatt and La Tène Periods, and from later periods especially as deposits in the ground or in peat-bogs. There is evidence that they were worn by gods as well as by prominent persons. In Greek-Roman pictorial art and literature the torc is the distinctive feature of a Celt. In Central Europe like in Southern Scandinavia, the neck-ring was used as a religious symbol. It was used as a sacrificial gift and considered as a divine attribute.

\section{Evidence from Greek and Roman Authors Regarding the Use of Neck-Rings Among the Celts and Germans}

Testimonies concerning the taste for neck-rings among the Celts and Germans can be found not only through archaeological finds but recorded by a number of ancient authors as well.

The oldest statement comes from Polybius, who was active during the third century B.C. He described the history of Rome in 40 books, of which five have been completely preserved. In his second book he describes the battle at Telamon in 225 B.C. In this fight two Roman armies completely defeated a large Celtic army. A Roman consul was killed, after which his head was cut off and carried to the Celtic king on a spear. One of the Celtic kings, Cocolitanus, was taken prisoner, while the other one, Aneroëstes, managed to escape but committed suicide.

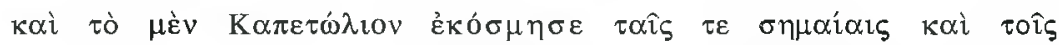

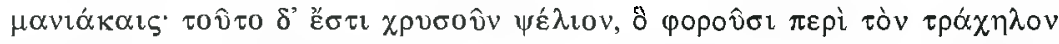

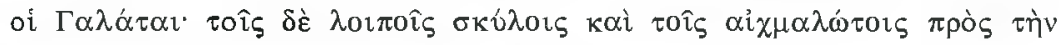

\footnotetext{
${ }^{18}$ A large number of pictures illustrating this can be found in Green 1989, MacCana 1970 and Moreau 1958.
} 


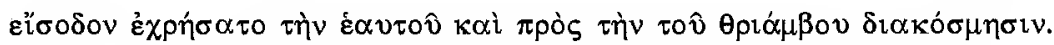
(Polybius 1960: II, 31, 5-6)

He sent to ornament the Capitol the standards and necklaces (the gold necklets worn by the Gauls), but the rest of the spoil and the prisoners he used for his entry into Rome and the adornment of his triumph. (Translation by W. R. Paton)

From the report of Polybius it may be concluded that L. Aemilius selected two types of things from the rich booty to dedicate to the gods at Capitolium. These were the banners of the enemies and their neck-rings. The banners were to a special degree perceived as the attributes of the defeated Celtic army. The fact that the Romans, beside the banners, chose the torcs of the vanquished indicates that they also stood out as powerful symbols for the defeated Celtic army.

Diodorus Siculus was a Greek historian from Sicily, living in the last century B.C. His world history comprises 40 books and covers the space of time until 54 B.C., i.e. to the time of the Gallic wars of Caesar. Diodorus incorporated many statements from earlier authors, including Poseidonios. Thanks to this, valuable information has been preserved to posterity from sources which have since vanished.

In the text below Diodorus describes how the Celts, women as well as men, adorned themselves with heavy torcs of solid gold, which they also brought forth as sacrifices to their gods.

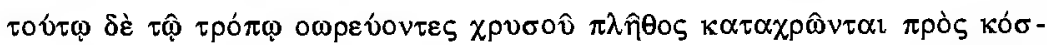

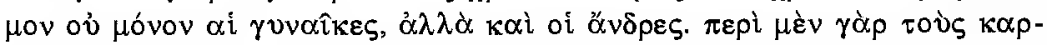

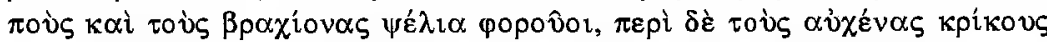

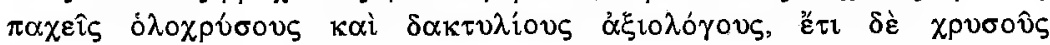

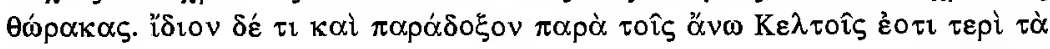

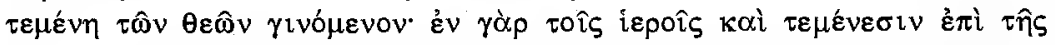

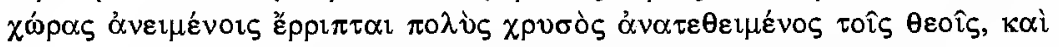

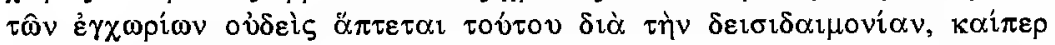

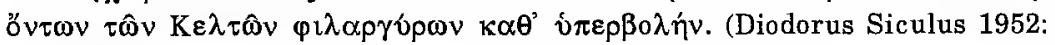
$\mathrm{V}, 27,3-4)$

In this manner they amass a great amount of gold, which is used for ornament not only by the women but also by the men. For around their wrists and arms they wear bracelets, around their necks heavy necklaces of solid gold, and huge rings they wear as well, and even corselets of gold. And a peculiar and striking practice is found among the upper Celts, in connection with the sacred precincts of the gods; for in the temples and precincts made consecrate in their land, a great amount of gold has been deposited as a dedication to the gods, and not a native of the country ever touches it because of religious scruple, although the Celts are an exceedingly covetous people. (Translation by C.H. Oldfather) 
The significance of the torc as an ethnic attribute for the Celts and as a sign of bravery is evident from the following report by Livius. Titus Livius, who was active in Rome in the days of the Emperor Augustus, wrote 142 books, giving an account of the history of Rome from the earliest time.

armatum adornatumque adversus Gallum stolide laetum et-quoniam id quoque memoria dignum antiquis visum est-linguam etiam ab inrisu exserentem producunt. Recipiunt inde se ad stationem, et duo in medio armati spectaculi magis more quam lege belli destituuntur, nequaquam visu ac specie aestimantibus pares. Corpus alteri magnitudine eximium, versicolori veste pictisque et auro caelatis refulgens armis: media in altero militaris statura modicaque in armis habilibus magis quam decoris species. Non cantus, non exsultatio armorumque agitatio vana, sed pectus animorum iraeque tacitae plenum; omnem ferociam in discrimen ipsum certaminis distulerat. Ubi constitere inder duas acies, tot circa mortalium animis spe metuque pendentibus, Gallus velut moles superne imminens proiecto laeva scuto in advenientis arma hostis vanum caesim cum ingenti sonitu ensem deiecit; Romanus mucrone subrecto, cum scuto scutum imum perculisset totoque corpore interior periculo volneris factus insinuasset se inter corpus armaque, uno alteroque subinde ictu ventrem atque inguina hausit et in spatium ingens ruentem porrexit hostem. Iacentis inde corpus ab omni alia vexatione intactum uno torque spoliavit, quem respersum cruore collo circumdedit suo. ... Inter carminum prope in modum incondita quedam militariter ioculantes Torquati cognomen auditum; celebratum deinde posteris etiam familiaeque honori fuit. (Livius 1953: VII, X, 5-11, 13)

Armed and accoutred, they led him forth to the Gaul, who in his stupid gleefor the ancients have thought even this worth mentioning-thrust his tongue out in derision. They then retired to their station, and the two armed men were left by themselves in the midst, like gladiators more than soldiers, and by no means evenly matched, to judge from outward show. One had a body extraordinary for its size, and resplendent in a coat of shifting hues and armour painted and chased with gold: the other was of a middling stature for a soldier, and his arms were but indifferent to look at, being suitable but not ornate. He neither sang nor danced about with idle flourishes of his weapons, but his bosom swelled with courage and silent wrath, and all his ferocity was reserved for the crisis of the combat. When they had taken their ground between the two embattled armies, while the hearts of the surrounding multitude were suspended betwixt hope and fear, the Gaul, whose huge bulk towered above the other, advanced his shield with the left arm, to parry the attack of his oncoming enemy, and delivered a slashing stroke with his sword, that made a mighty clatter but did no harm. The Roman, with the point of his weapon raised, struck up his adversary's shield with a blow from his own against its lower edge; and slipping in between the man's sword and his body, so close that no part of his own person was exposed, he gave one thrust and then immediately another, and gashing the groin and belly of his enemy brought him headlong to the ground, where he lay stretched out over a mon- 
strous space. To the body of his fallen foe he offered no other dignity than to despoil it of one thing-a chain which, spattered with blood, he cast round his own neck. ... Amidst the rude banter thrown out by the soldiers in a kind of verse, was heard the appellation of Torquatus, and thereafter this was given currency as an honoured surname, used even by descendants of the family. (Translation by B. O. Foster)

Livius describes a duel between the Roman Titus Manlius and a Celt. Before the beginning of the fight the latter jeered at Manlius by sticking out his tongue at him. The two men fought with each other, dressed in swords and shields. The Gallic warrior was defeated and killed by Manlius, who then took away his torc. As an award for his victory Manlius received the honorary title Torquatus with the right, even for his descendants, to carry this name.

The following text describes an event, which is said to have taken place around 390 B.C. in the vicinity of Massilia in the ancient Gaul. It is described in Epitoma Historiarum Philippicarum by Marcus Junianus Justinus. This work, which was probably written in the third century A.D., is in its turn an extract from Historiae Philippicae, the world history of Pompejus Trogus, from the beginning of our time. The text below describes how the Celtic tribal king Catumandus sacrificed a torc to Minerva.

Dux consensu omnium Catumandus regulus eligitur. Qui cum magno exercitu lectissimorum virorum urbem hostium obsideret, per quietem specie torvae mulieris, quae se deam dicebat, exterritus ultro pacem cum Massiliensibus fecit, petitoque ut intrare illi urbem et deos eorum adorare liceret, cum in arcem Minervae venisset, conspecto in porticibus simulacro deae, quam per quietem viderat, repente exclamat illam esse, quae se nocte exterruisset, illam, quae recedere ab obsidione iussisset. Gratulatusque Massiliensibus, quod animadverteret eos ad curam deorum inmortalium pertinere, torque aureo donata dea in perpetuum amicitiam cum Massiliensibus iunxit. (Justinus 1935: 43, 5-7)

The tribal king Catumandus was elected commander by general agreement. While surrounding the city with a great army of his best warriors, he saw in his sleep a threatening woman, who said she was a goddess. Terrified, he voluntarily made peace with the inhabitants of Massilia and asked them to be allowed to enter the city in order to worship their gods. When he entered the temple of Minerva he saw in its arcade a statue of the goddess he had seen in his sleep, and at once he exclaimed that this was the goddess who had terrified him in the night and had ordered him to relinquish the siege. He congratulated the inhabitants of Massilia, as he now understood that they were under the protection of the immortal gods, and he presented the goddess with a golden torc and made a treaty of everlasting friendship with the inhabitants of Massilia. (My translation) 
Tacitus tells us in his Germania, written in the first century A.D., the following:

Mos est ciuitatibus ultro ac uiritim conferre principibus uel armentorum uel frugum, quod pro honore acceptum etiam necessitatibus subuenit. Gaudent praecipue finitimarum gentium donis, quae non modo a singulis, sed et publice mittuntur, electi equi, magnifica arma, phalerae torquesque; iam et pecuniam accipere docuimus. (Tacitus 1935: XV)

It is the custom in their states for each man to give away to the chiefs some portion of one's cattle or crops. This is accepted as an honour but serves their needs as well. Above all they rejoice in the gifts of neighbouring tribes, which are sent not only by individuals but also by the community: selected horses, excellent armour, bosses, and necklaces. Nowadays we have taught them to accept money as well. (My translation)

Tacitus describes how luxury goods were sent as gifts from one leader to another and from one tribe to another. Torcs were evidently among the things that were used and highly appreciated by the Germans.

Another Roman author, Lucius Annæus Florus, who was active in the second century A.D., describes how the men of Ariovistus ${ }^{19}$ dedicated a torc, which had been captured from the enemy, to their warrior god.

Mox Ariouisto duce uouere de nostrorum militum praeda Marti suo torquem. (Florus 1967: I, XX)

Soon afterwards, when Ariovistus was their leader, they vowed to dedicate to their War-god a necklet made from the spoils of our soldiers. (Translation by Edward Seymour Forster)

Here the torc is a votive offering to the Germanic warrior god, delivered with the hope of further success in the field. However, it is clear from the text of Florus that this expectation was not fulfilled.

The fact that torcs were not only reserved for men, but could also be worn by distinguished women, is confirmed by Cassius Dio. This GreekRoman politician and historian has given an account of the history of Rome until 229 A.D.

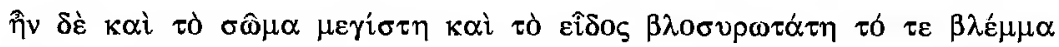

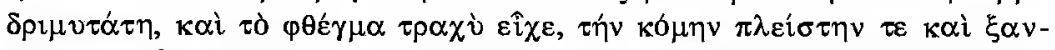

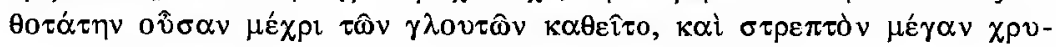

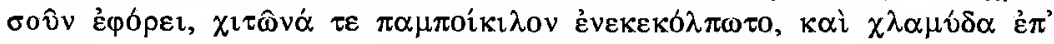

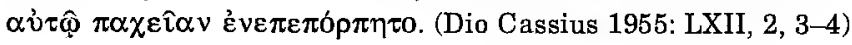

\footnotetext{
${ }^{19}$ Ariovistus was the leader of the Suevi, a Germanic tribe comprising Semnones, Marcomanni and Alamanni, who were defeated by Caesar in Gaul in 58 B.C.
} 
In stature she was very tall, in appearance most terrifying, in the glance of her eye most fierce, and her voice was harsh; a great mass of the tawniest hair fell to her hips; around her neck was a large golden necklace; and she wore a tunic of diverse colours over which a thick mantle was fastened with a brooch. This was her invariable attire. (Translation by Earnest Cary)

In this text Dio describes Buducia, a Celtic woman of royal descent, who was distinguished by the fact that she wore a huge golden torc. We know of this Boudicca (Buducia) that she was not only a queen but also an eminent military commander during a violent and bloody rebellion against the Romans in Britain. At last the army of Boudicca was defeated by the Roman commander Suetonius Paulinus, and in 61 A.D. she committed suicide to avoid being taken prisoner and executed. ${ }^{20}$

Prokopius, a Byzantine historian in the sixth century A.D., who served as a secretary to the East-Roman commander Belisarios, has described the many military campaigns of Belisarios. Among others Belisarios defeated the Vandals and the Goths on account of the Roman emperor Justinianus I. In this connection Prokopius mentions with enthusiasm Belisarios' generosity towards his soldiers, who to a great extent had been recruited from the Germanic tribes.

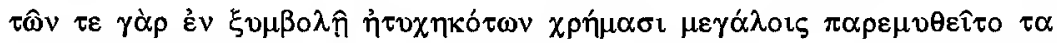

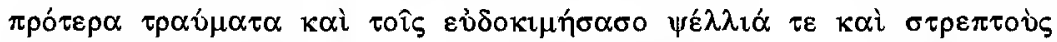

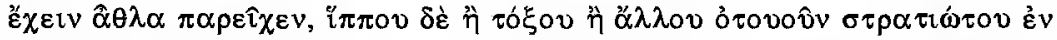

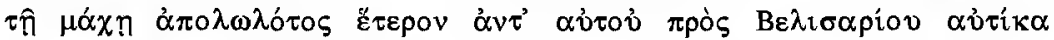
$\hat{0} \pi \hat{\eta} \rho \chi \varepsilon v \cdot$ (Procopius 1924: VII, I, 8)

for when any had met with misfortune in battle, he used to console them by large presents of money for the wounds they had received, and to those who had distinguished themselves he presented bracelets and necklaces to wear as prizes, and when a soldier had lost in battle horse or bow or anything else whatsoever, another was straightway provided in its place by Belisarius (Translation by H.B. Dewing)

In the account of Prokopius the neck-rings are rewards for courage in battle. Consequently they stand out as counterparts to the medals for bravery of today. They are signs of dignity, distinguishing the courageous warrior from the great mass of warriors.

This interpretation gets support from another passage in Prokopius' description of the war against the Goths. In VIII, XXXI,8-9 he describes how the Gothic king Totila and his adversary Narses arranged their armies for battle. Both Totila and Narses tried to infuse courage and fighting spirit

\footnotetext{
${ }^{20}$ Concerning Boudicca and her destiny see also Rankin 1987: 220-223.
} 
into their soldiers by raising arm- and neck-rings as well as golden bridles into the air.

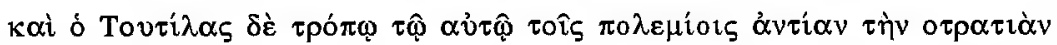

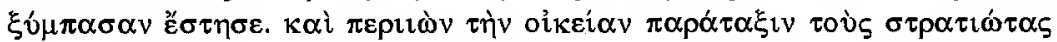

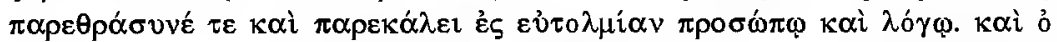

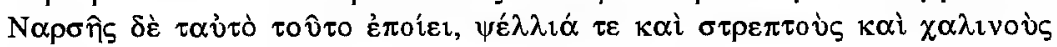

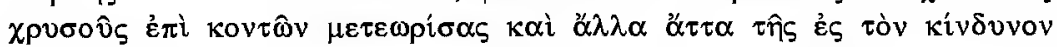

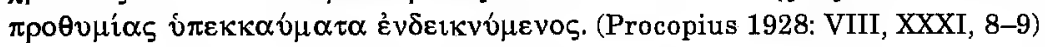

And Totila arrayed his army in the same way opposite his enemy. Then going along his own battle-line he kept encouraging his soldiers with voice and expression and urging them to boldness. Narses likewise did the same thing, holding in the air bracelets and necklaces and golden bridles on poles and displaying certain other incentives to bravery in the coming struggle. (Translation by H.B. Dewing)

\section{Discussion}

In the documents from the centuries around the beginning of our time, quoted here, the Celts are at the focus of interest of the Romans, and the texts describe their use of torcs. Later accounts describe how Germanic people value and use neck-rings as well. Thus, the importance of the neckring is certified among the tribes called Celts by the Romans, as well as among those they called Germans. The most probable explanation for this might be that the Romans first came into contact with the Celts, and somewhat later with the Germans. ${ }^{21}$

The account of Polybius makes it clear that the Celts were characterized by their use of the torc as early as in the third century B.C. For the Romans the torc was understood as an ethnic characteristic of the Celts. ${ }^{22}$

The fancy for beautiful and expensive golden objects among the Celts is a well known and certified fact, not least through the archaeological finds. Diodorus Siculus recounts how the Celts made golden torcs and dedicated their gold to the gods by setting it out on holy places. The neck-rings were

${ }^{21}$ Our current picture of certain peoples and tribes as Celts and others as Germans rests on an arbitrary division made by the Greeks and Romans. The river Rhine became a boundary. People living north and east of this line were called Germans, while the tribes to the south and west were called Celts. With regard to cultural forms and behavioural patterns Germans and Celts were very similar to each other. This similarity was early pointed out by Poseidonios. See Strabo 1923: 4.4.2. This is also evident from research, described among others in Hachmann, Kossack and Kuhn 1962.

${ }^{22}$ This conclusion gets support also from the well-known statue of the dying Gaul, created in the third century B.C. See picture 17. 
carried by men as well as women. Consequently, it seems as if the neckring had several meanings. It was a sign of personal wealth and prestige, but it also had a function in the cult which cannot be explained by the value of the metal only.

This is also evident from Trogus' description of the siege of Massilia and its abandonment. The Celtic commander Catumandus presented a golden torc to the goddess Minerva as a sign of his deep reverence, after having raised the siege.

Livius, active at the beginning of our time, points to the torc as a symbol of the warrior. The fact that Manlius received the name of Torquatus after his victory over the Celtic warrior indicates that the torc had not only an economic value, but that to have obtained a torc was a special honour.

The account of Tacitus makes it clear how the Germanic tribal kings exchanged prestigious objects as a sign of friendship. The transfer of such objects, including torcs, so common among the Scandinavian archaeological finds, might have taken place in the way Tacitus describes.

Cassius Dio makes it clear that the torc was not an exclusively male symbol. But Boudicca, who used to wear a torc, was not an ordinary woman, but a queen and a military leader. In this case the torc seems to have been a sign of leadership.

The two excerpts from the books of Prokopius, written as late as in the sixth century A.D., show that the torc served as a reward for and as an incentive to bravery in battle.

Consequently, the written accounts collected here show that above all men, but at times also women, used the neck-ring on Celtic as well as on Germanic territory. The texts also make it clear that the neck-ring was a symbol of bravery, leadership, and prestige, and that it served a sacrificial function as a divine attribute and as an offering. The archaeological finds from both cultural territories confirm the image given by the ancient and medieval authors.

\section{Necklaces in the Vendel and Viking Age (550-1050 A.D.)}

The custom in southern Scandinavia of depositing neck-rings in bogs and swamps as well as in the earth, which characterized the period from the Late Bronze Age to the Migration Period, did not come to an end with the Migration Period, but it became weaker and took new forms.

The finds from peat-bogs, which are clearly offerings, are fewer from the Vendel and Viking Age than from earlier times. The custom of laying down 
objects in bogs and swamps as offerings to the gods can be traced as far back as to the Neolithic time, but now it seems to have decreased. Instead deposits in the ground became more common during the Viking Age, even if occasional offerings in bogs were still made. A find of this kind originates from Hon in southern Norway. This find, consisting of both gold and silver objects, was found in a bog and has been interpreted as a temple hoard (Brøndsted 1960: 345)

The golden objects, so dominating in the finds from the Migration Period, are much less frequent in the finds from the Viking Age. For instance, a golden neck-ring was found in Fjälkestad in Skåne. It is a twisted ring with a loop in one end and a hook in the other. This ring was found in connection with ploughing (Strömberg 1963: 116-117). Similar twisted gold rings are parts of finds from, above all, the later part of the Viking Age. In the finds from this time, however, silver objects are much more frequent (Munksgaard 1970: 28).

Silver objects deposited in the ground constitute a large group of finds in Denmark as well as in Sweden and Norway. In Sweden alone around 1100 silver hoards have been found. The Viking Age has even been called the Silver Age of Scandinavia, because of the importance silver had during that time as a metal for jewellery and as a standard of value. Silver was acquired through commercial connections with the Arabs, who had started to exploit new silver finds in Arabia (Munksgaard 1970: 25). The majority of the Swedish silver finds have been made on the isles of Öland and Gotland, but a great number of finds are also made in Skane and in the area around Lake Mälaren. ${ }^{23}$ Many of the finds, especially from Gotland, are very large. An example is the find from Burge in the parish of Lummelunda, with a total weight of more than $10 \mathrm{~kg}$ of silver. The largest Danish silver find, which originates from Terslev on the isle of Sjælland, weighs $6.5 \mathrm{~kg}$. The great majority of the finds are dated to the $10^{\text {th }}$ and $11^{\text {th }}$ centuries, and a minority to the $9^{\text {th }}$ century.

The silver finds often consist of different kinds of jewellery. These are dominated by artistically twined neck-ornaments and arm-rings. (Picture 18) The Danish find from Vester Vedsted, including two neck-rings, and the find from Terslev mentioned above, containing four silver neck-rings, might be mentioned as examples. ${ }^{24}$ In Sør-Trøndelag in Norway several

\footnotetext{
${ }^{23}$ Stenberger 1947 makes a description of all finds of this type from Gotland dating to the Viking Age, known in the 1940s.

${ }^{24}$ Concerning these two finds, see Munksgaard 1970: 28-29, and for the Terslev find also Asmussen 1985: 243-244.
} 
finds have been made of as many as six large, heavy rings, often found together with ring needles and golden arm-rings (Hårdh 1992: 103).

The finds consist not only of intact jewellery, but also of silver bars or rods, coins and hacksilver. The coins are often of Arab or Western European origin. Hacksilver consists of silver cut into pieces, generally considered to have been used for payment according to weight.

Even neck-rings, cut into pieces, count as hacksilver. This is not a completely new phenomenon. The finds from the Migration Period sometimes contain neck-rings and arm-rings, cut into pieces. One instance of this is the great gold hoard from Broholm on the southern part of Fyn in Denmark consisting of 51 gold objects with a total weight of $4.154 \mathrm{~kg}$. The find contains, among others, three solid neck-rings, the largest of them with a weight of $1.356 \mathrm{~kg}$. Around the ring a thin golden thread has been wired. It further contains some pieces of jewellery, such as seven bracteates, as well as gold fragments from rings, which have been cut into pieces, and gold bars. Thus, the hoard consists both of intact pieces of jewellery and of fragments, which archaeologists regard as payment gold (Munksgaard 1970: 11-12).

The question of payment gold and silver raises the problem of the interpretation of the silver finds from the Viking Age. Scholars have suggested many different explanations for the fact that they were once deposited in the ground. Two suggestions, however, have dominated the debate. According to one of them they were buried out of fear of war or assaults from pirates. The ground would then have been used as a kind of safe deposit. According to the other suggestion, the silver objects were offerings to the gods. ${ }^{25}$

The question why the silver was deposited in the earth has become complicated, because so many of the silver finds have been made by chance while preparaing the ground. Because of this the precise circumstances of the finds are often unclear. Many objects have been lost or left in the ground. Because of this the Swedish Central Board of National Antiquities took the initiative in 1977 to make supplementary examinations of familiar finding-places on Gotland. These new investigations have proved that the finding-places have often been situated in dwelling-houses in farms from the Viking Age. The silver was left there when the houses were abandoned. The common understanding among archaeologists was previously that the silver was deposited outside the farms. Majvor Östergren, who was responsible for this project on Gotland, suggests that the silver might have

\footnotetext{
${ }^{25}$ A survey of the different interpretations can be found in Stenberger 1958: 307-320.
} 
been individual property, which was left untouched after the death of the owners (Östergren 1983). On this presumption a possible explanation might be provided by a passage in the Ynglingasaga of Snorri Sturluson, which has often been quoted by archaeologists as an explanation for deposits from divergent times:

sagði hann [Óðinn] svá, at með pvílíkum auðœfum skyldi hverr koma til Valhallar, sem hann hafơi á bál; pess skyldi hann ok njóta, er hann sjálfr hafơi í jörd̃ grafit (Snorri Sturluson 1911: 8)

[Óđinn] said that each man should come to Valhall with the properties he had on his funeral pyre, and in addition he should use all that he had buried in the earth. (My translation)

\section{Discussion}

In the Viking Age offerings only exceptionally took place in the bogs and swamps that had been functioning as cult places for such a long time. However, the depositing of objects in the ground continued and increased. On Gotland new investigations have been able to show that the silver was to a very great extent buried within the houses and left there when the houses were abandoned. This is a new theory that could contribute to an understanding of the finds from the Viking Age.

While gold was the precious metal typical of the Migration Period, the Viking Age is characterized by silver. The silver finds often consist of entire ornaments as well as those that are cut into pieces, rods and bars of silver, and coins. Neck-rings and arm-rings dominate the finds of ornaments and are in general found together, while finds of only neck-rings are uncommon, contrary to earlier times. Neck-rings and arm-rings cut into pieces, which are common in the silver finds from the Viking Age, are in general believed to have been used as means of payment. Occasional finds of this kind are known from the Migration Period. This is something quite different from the deliberate, violent destruction, that characterizes so many of the great finds in peat-bogs from the Iron Age. ${ }^{26}$

So far I have given evidence that there exists in southern Scandinavia a continuous tradition of deposits of neck-rings, mainly in bogs and streams, but also in the ground, from the Early Bronze Age into the Viking Age. Over a time span of more than 1000 years neck-rings were given as offerings to the gods, they decorated idols and probably also served as symbols for one or several deities.

\footnotetext{
${ }^{26}$ Concerning ritual demolition see Görman 1987.
} 
During the Viking Age some changes seem to have taken place. The swamps lost their exceptional position as places for cult. Silver replaced gold and bronze as the foremost precious metal. Neck-rings and arm-rings still dominated in the deposits, but offerings of neck-rings only were uncommon. Moreover, the rings were now often cut into pieces, although there is no reason to believe that this was a ritual practice. In Norway, however, the old custom of depositing large and heavy neck-rings continued.

\section{Some Examples of the Neck-Ring as a Motif in Old Icelandic Literature}

In this section I use a number of examples to point out that the neck-ring is also a subject of interest in Old Icelandic Literature.

Oðinn is the owner of the ring Draupnir. Snorri describes how this ring came into existence. The two dwarfs Eitri and Brokkr made it together, and later they presented it to Orinn with the information that every ninth night eight new rings, as heavy as Draupnir, would drop from it (Snorri Sturluson 1931: 123-4). A kenning for gold in the Icelandic poetry is "dögg Draupnis" (the dew of Draupnir), hinting at the capacity of Draupnir to multiply.

Draupnir appears again in a poem of the Poetic Edda, called Skírnismál. The poem describes the love of the god Freyr for Geror, the fair daughter of a giant. Freyr's servant Skírnir makes a proposal of marriage to Geror on behalf of the god, and he promises her gold if she is willing to love Freyr. Geror, however, is not tempted. Then Skírnir raises the bid:

[Skírnir] kvað:

Baug ek pér pá gef, pann er brendr var með̃ ungom Óđins syni; átta ero iafnhöfgir, er af driúpa ena níundo hveria nótt.

[Gerðr] kvað:

Baug ek pikkak, pótt brendr sé mep ungom Óðins syni; era mér gullz vant í görðom Gymis, 
at deila fé föður.

(Eddadigte 1952: 27)

(Skírnir said:)

"Draupnir, the ring,

then thy dowry shall be,

which with Baldr was burned;

eight rings as dear

will drop from it

every ninth night."

(Gerth said:)

"Draupnir, the ring,

I do not want, though it with Baldr was burned;

gold I lack not

in Gymir's halls,

to deal out daily."

(Translation by Lee M. Hollander)

Thus, Gerơr was not convinced even by Skírnir's promise to present her Draupnir.

Snorri informs us that Oð̇inn placed his ring on the funeral pyre of Baldr when the latter was killed by the blind god Höðr by means of a mistletoe branch. Hermóor made for Hel in order to offer a ransom for the dead Baldr. Baldr then sent Draupnir back with Hermóðr. ${ }^{27}$

Freyja, the goddess, had many names. One of them was Menglöd, "the neck-ring-lover". This name was probably attributed to her because she was in possession of the necklace Brísingamen. This ring was, together with her cats, her main attribute.

Snorri writes:

Hvernig skal Freyiv keNa? Sva, at kalla dottvr Niarbar, systvr Freys, konv Ops, Mopvr Hnossar, eigandi valfallz ok Sesrvmnis ok fressa, Brisingamens, Vana goð, Vana dis, it gratfagra goð, [asta gvð. (Snorri Sturluson 1931: 110)

How shall Freyia be referred to? By calling her daughter of Niord, sister of Freyr, wife of Od, mother of Hnoss, possessor of the fallen slain and of Sessrumnir and tom-cats, of Brisingamen, Van-deity, Van-lady, fair-tear deity. (Translation by Anthony Falkes)

Freyja is also called Mardöll, and a kenning for gold is "Mardallar tár" or "Mardallar grátr" (Mardöll's tears). ${ }^{28}$ This designation might hint at the golden Brísingamen, which Freyja was in the possession of.

\footnotetext{
${ }^{27}$ Baldr is also called "the owner of Draupnir" by Snorri. See Snorri Sturluson 1931: 97.

${ }^{28}$ Concerning the name see Snorri Sturluson 1931: 38.
} 
The fact that Brísingamen was the special characteristic of Freyja is also evident from Prymskviða in the Poetic Edda. This poem recounts how Prym, the giant, ran away with the hammer of Pórr, the god. In order to return the hammer Prym demands Freyja as his bride. When she refuses, Heimdallr, the god, finds a way. He proposes that Pórr himself should dress in bridal linen and the Brísingamen of Freyja and make for Prym. The trick is successful and after some complications Pórr regains his hammer.

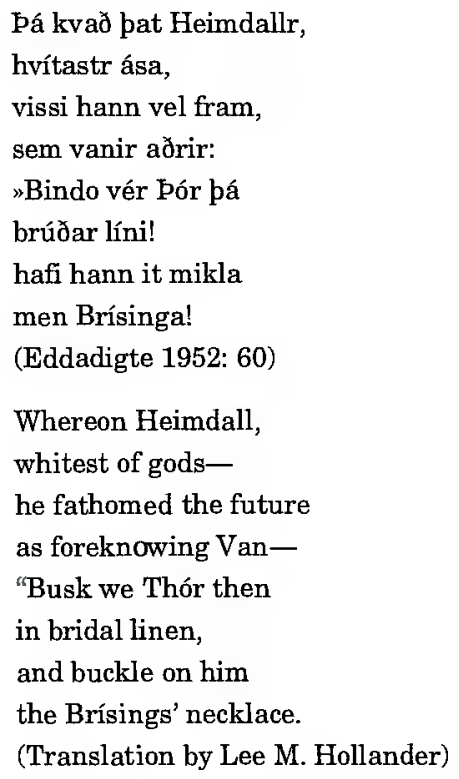

In Sörla páttr we are told how Freyja acquired Brísingamen. In a stone close to the dwelling-place of the goddess some dwarfs were living. A golden necklace, which the dwarfs were forging, caught her attention, and she was charmed by it. She bargained with the dwarfs and offered them gold, silver and other articles of value. This, however, did not tempt the dwarfs. Instead they demanded that she should sleep one night with each one of them in order to receive the desirable object. This was done, and Freyja acquired the necklace. But then Loki told Oðinn how Freyja had gained it, whereupon Óðinn gave him the task to extort it from her.

Loki managed to sneak into the dwelling-place of the goddess by turning into a fly. Well inside he managed to deprive her of the necklace by taking on the guise of a flea. Now Freyja reclaimed the neck-ring from Oððinn. But in order to regain it she was forced to arrange for two kings with many vassals under them to fight under wizardry, so that they could stand up 
again as soon as they had fallen and continue the battle (Flateyjarbók 1860: 275-276).

\section{Discussion}

It is evident from the texts that the neck-ornament is an important attribute both of Oð̇inn and of Freyja. Draupnir, as well as Brísingamen, is the subject of great interest from the surrounding individuals. The rings carry names of their own. Freyja is named by reference to her necklace. In Skírnismál óðinn's ring was offered as a bridal gift. Draupnir has a special function, as it is placed on the funeral pyre of Baldr. In several stories one of the rings has an important part in the course of events.

In the scientific discussion Óðinn's ring has sometimes been understood as a neck-ring, but also as an arm-ring. Its power to multiply itself, by dropping eight new rings of the same weight every ninth night, has been interpreted as a symbol of constantly growing wealth. However, more farreaching speculations can be found as well. For instance the theory advocated by Jan de Vries might be mentioned. According to his conjecture, Draupnir is a symbol for a week with nine days. His theory includes the idea of an old calendar based on a moon year (Vries 1957: 78-79).

Brísingamen has also been understood as a necklace in the scientific discussion. But it has also been interpreted as a symbol of the red light of dawn, of the sun, and even of the cultic fire (Vries 1957: 311-312). An imaginative explanation, which has gained some influence, has been put forward by Birger Pering. In his version Brísingamen is an amulet, consisting of a reddish brown fruit from a specific West Indian plant, carried towards the north by the Gulf Stream. According to Pering, this fruit could in the popular tradition alleviate throes of childbirth, and the pregnant woman could carry it in her hand or tied to her body (Pering 1941: 210227).

This means that research on the whole has been characterized by scholars who have not been aware of the continuity I have pointed out in this article.

\section{Conclusions}

It is no coincidence that the neck-ornament occupies an important place in Old Icelandic Literature. Instead this reflects a long tradition, where the neck-ring was used as a distinctive feature, as a symbol of prestige, and filled a religious function. In a religious connection it served as a divine 
attribute as well as an offering to the gods. This tradition was not limited to Scandinavia; it is also accounted for in large parts of Europe.

\section{Acknowledgement}

The research made for this article was supported by a a grant from the Swedish Council for Research in the Humanities and Social Sciences.

\section{References Cited}

Albrectsen, Erling

1990 Kedlen fra Rynkeby. In: Poul Kjærum and Rikke Agnete Olsen (eds.), Oldtidens ansigt. Til hendes majestaet dronning Margrethe II 16. april 1990; pp. 98-99. København: Det kongelige nordiske oldskriftselskab.

Arbman, Holger

1948 Gundestrupkitteln - ett galliskt arbete? Tor 1: 109-116.

Asmussen, Else

1985 Terslevfundet. In: Lotte Hedeager and Kristian Kristiansen (eds.), Arkæologi Leksikon; pp. 243-244. Kø̋benhavn: Politikens forlag.

Bjørn, Anathon

1926 Tidlig metalkultur i Østnorge. Oldtiden, tidsskrift for norsk forhistorie 11: 1-76.

Broholm, H. C.

1943-49 Danmarks bronzealder; 4. vols. København.

Burenhult, Göran

1991 Arkeologi I Sverige; vol. 3: Samhällsbyggare och handelsmän. Höganäs: Förlags Ab Wiken. [2nd ed.]

Brøndsted, Johannes

1929 Guldringen fra Taastrup. Fra nationalmuseets arbejdsmark 1929: 67-68.

1938 To guldhalsringe fra folkevandringstid. Fra Nationalmuseets arbejdsmark 1938: 29-34.

1958 Danmarks oldtid; vol. 2: Bronzealderen. Copenhagen: Gyldendal. [2nd ed.]

1960 Danmarks oldtid; vol. 3: Jernalderen. Copenhagen: Gyldendal. [2nd ed.]

Collis, John

1984 The European Iron Age. London: Batsford.

Dio Cassius

1955 Dio's Roman history; vol. 8 Cambridge: Harward University Press. (The Loeb Classical Library, 176)

Diodorus Siculus

1952 Diodorus of Sicily in twelve volumes. Cambridge: Harward University Press. (The Loeb Classical Library, 279) 
Djupedal, Reidar, and H. C. Broholm

1952 Marcus Schnabel og bronzealderfundet fra Grevensvænge. København: Gyldendalske Boghandel. (Aarbøger for nordisk oldkyndighed og historie)

Drexel, F.

1915 Über den Silberkessel von Gundestrup. In: Jahrbuch des kaiserlichen deutschen archäologischen Instituts 30 ; pp. 1-36. Berlin.

Duval, Paul-Marie

1991 Celtic Art. In: Sabatino Moscati et al. (eds.), The Celts; pp. 25-28. Milano: Bompiani.

Eddadigte

1952 Eddadigte. II Gudedigte. Ed. by Jón Helgason. København: Munksgaard.

Filip, Jan

1970 Keltische Kultplätze und Heiligtümer in Böhmen. In: Herbert Jankuhn (ed), Vorgeschichtliche Heiligtümer und Opferplätze in Mittelund Nordeuropa; pp. 55-77. Göttingen: Vandenhoeck u. Ruprecht.

Flateyjarbók

1860 Flateyjarbók. En samling Norske Kongesagaer; vol. 1. Ed. by G. Vigfússon and C. R. Unger. Christiania.

Florus, L. Annaeus

1967 Euvres; vol. 1. Ed. by Paul Jal. Paris.

Glob, P. V.

1969 Helleristninger i Danmark. København: Jysk arkæologisk selskab. (Jysk arkæologisk selskabs skrifter, 7)

Goessler, Peter

1929 Der Silberring von Trichtingen. Festschrift der archäologischen Gesellschaft zu Berlin. Berlin und Leipzig: Walter de Gruyter \& Co.

Görman, Marianne

1987 Nordiskt och keltiskt. Sydskandinavisk religion under yngre bronsålder och keltisk järnålder. Lund: Lunds universitet.

Green, Miranda

1989 Symbol and Image in Celtic Religious Art. London: Routledge.

Hårdh, Birgitta

1992 Ekonomiska regioner i Norden och Östersjöområdet. In: Egil Mikkelsen and Jan Henning Larsen (eds.), Økonomiske og politiske sentra i Norden ca 400-1000 e.Kr. Oslo: Universitetets Oldsakssamling. (Universitetets Oldsakssamlings Skrifter, N. R., 13)

Hachmann, Rolf, Georg Kossack, and Hans Kuhn

1962 Völker zwischen Germanen und Kelten. Schriftquellen, Bodenfunde und Namengut zur Geschichte des nördlichen Westdeutschlands um Christi Geburt. Neumünster: Karl Wachholtz Verlag.

Hagberg, Ulf Erik

1967 The Archaeology of Skedemosse 2, vols. Stockholm: Almqvist \& Wiksell. 
Hauck, Kar1

1954 Halsring und Ahnenstab als herrscherliche Würdezeichen. In: Percy Ernst Schramm (ed.), Herrschaftszeichen und Staatssymbolik 1; pp. 145-212. Stuttgart.

\section{Holmqvist, Wilhelm}

1980 Guldhalskragarna. Stockholm: Lts förlag.

Hyenstrand, Åke

1968 Gravformer och symboltecken under yngre bronsålder. Fornvännen 63: $185-189$.

Justinus, Marcus Iunianus

1935 Epitoma historiarum Philippicarum Pompei Trogi. Ed. by Otto Seel. Leipzig.

Kaul, Flemming

1991 The Ball Torques. Celtic Art outside the Celtic World. In: Sabatino Moscati et al. (eds.), The Celts; p. 540. Milano: Bompiani.

Kivikoski, Ella

1947 Die Eisenzeit Finnlands. Bilderatlas und Text; vol. 1. Porvoo: WSOY.

Kjær, Hans

1927 To votivfund fra yngre bronzealder, fra Fyen og Jylland. København: Gyldendalske Boghandel. (Aarbøger for nordisk oldkyndighed og historie, 1927-28)

Klindt-Jensen, Ole

1957 Bornholm i folkevandringstiden og forudsætningerne i tidlig jernalder, København: Nationalmuseet. (Nationalmuseets skrifter, Større beretninger, 2)

1961 Gundestrupkedelen. København: Nationalmuseet.

Lamm, Jan Peder

1991 Zur Taxonomie der schwedischen Goldhalskragen der Völkerwanderungszeit. Fornvännen 86: 153-167.

Livius, Titus

1953 Livy in fourteen volumes; vol. 3. Cambridge: Harward University Press. (The Loeb Classical Library, 172)

MacCana, Proinsias

1970 Celtic Mythology. London: Hamlyn.

Mackeprang, Mogens B.

1935 Menschendarstellungen aus der Eisenzeit Dänemarks. Acta Archaeologica 6: 228-249.

Montelius, Oscar

1912 Mästerstycken i Statens Historiska Museum. Stockholm.

Moreau, Jaques

1958 Die Welt der Kelten. Stuttgart: Gustav Klipper.

Mortensen, Peder

1991 The Brå Cauldron. In: Sabatino Moscati et al. (eds.), The Celts; p. 375. Milano: Bompiani.

Munksgaard, Elisabeth

1952 Collared gold necklets and armlets. A remarkable Danish fifth century group. Acta Archaeologica 23: 67-80. 
1970 Skattefund fra jernalderen. København. Nationalmuseet.

Müller, Sophus

1892 Det store sølvkar fra Gundestrup i Jylland. Nordiske Fortidsminder 1: $35-61$.

1900 En fremmed halsring af guld fra førromersk tid. Aarbøger for nordisk oldkyndighed og historie 1900: 140-143.

1917 Archæologisk udbytte av mosearbeidet i krigsaaret 1917. Aarbøger for nordisk oldkyndighet og historie 1917: 148-174.

1933 Oldtidens kunst i Danmark; vol. 3: Jernalderens kunst i Danmark, førromersk og romersk tid. Kjøbenhavn: Reitzels.

\section{Nylén, Erik}

1962 Skatten från Havors fornborg. In: Proxima Thule. Sverige och Europa under forntid och medeltid; pp. 94-112. Stockholm: Norstedt.

1967-68 Gundestrupkitteln och den thrakiska konsten. Tor 1967-68: 133173.

Östergren, Majvor

1983 Silverskatternas fyndplatser - farmännens gärdar. In: Ingmar Jansson (ed.), Gutar och vikingar; pp. 34-48. Stockholm: Statens historiska museum.

Oldsager

1979 Jeg ser på oldsager. Danske oldsager i tekst og billeder. København: Politikens forlag. [4th ed.]

Pering, Birger

1941 Heimdall. Religionsgeschichtliche Undersuchungen zum Verständnis der altnordischen Götterwelt. Lund.

Polybius

1960 The histories in six volumes; vol. 1. Cambridge: Harward University Press. (The Loeb Classical Library, 128)

\section{Procopius}

1924 Procopius in seven volumes; vol. 4. Cambridge: Harward University Press. (The Loeb Classical Library, 173)

1928 Procopius in seven volumes; vol. 5. Cambridge: Harward University Press. (The Loeb Classical Library, 217)

Raftery, Barry

1991 The Island Celts, In: Sabatino Moscati et al (eds.), The Celts; pp. 555571. Milano: Bompiani.

Rankin, H. D.

1987 Celts and the Classical World, London: Croom Helm.

Ross, Anne

1967 Pagan Celtic Britain. Studies in Iconography and Tradition. London: Routledge \& Kegan Paul

Snorri Sturluson,

1911 Heimskringla. Nóregs konungasögur. Ed. by Finnur Jónsson. København: G.E.C. Gads forlag.

1931 Edda Snorra Sturlusonar. Ed. by Finnur Jónsson. København: Gyldendalske boghandel. 


\section{Stenberger, Mårten}

1947 Die Schatzfunde Gotlands der Wikingèrzeit; vol. 2. Lund: Håkan Ohlssons boktryckeri.

1958 Die Schatzfunde Gotlands der Wikingerzeit; vol. 1. Stockholm: Almqvist \& Wiksell.

1964 Det forntida Sverige. Stockholm: Almqvist \& Wiksell.

Strabo

1923 The geography of Strabo in eight volumes; vol. 2. Cambridge: Harward University Press. (The Loeb Classical Library, 50)

Ström, Folke

1967 Nordisk hedendom. Tro och sed i förkristen tid. Göteborg: Akademiförlaget-Gumperts. [2nd ed.]

Strömberg, Märta

1963 Järnåldersguld i Skåne. Lund. (Från forntid och medeltid, 4)

Tacitus, Cornelius

1935 The Germania of Tacitus. Ed. by Rodney Potter Robinson. Middletown: Lancaster Press Inc.

Vebæk, Christen Leif

1944 En østjysk offermose fra keltisk jernalder. Fra nationalmuseets arbejdsmark 1944: 21-28.

Vries, Jan de

1957 Altgermanische Religionsgeschichte; vol. 2. Berlin. (Grundriss der germanischen Philologie, 12, 2) [2nd ed.]

\section{Walker, Henry}

1857 Notice of "The law" and other antiquities in the parish of Urquhart, near Elgin. In: Proceedings of the Society of Antiquaries of Scotland 1856-57; pp. 530-533. Edinburgh. 